Concordia University St. Paul

DigitalCommons@CSP

\title{
'A Body of Sound Practical Common Sense': Law Reform Through Lay Judges, Public Choice Theory, and the Transformation of American Law
}

Gregory S. Sergienko

Concordia University School of Law, gsergienko@cu-portland.edu

Follow this and additional works at: https://digitalcommons.csp.edu/lawfaculty

Part of the Commercial Law Commons, Judges Commons, and the Jurisprudence Commons

\section{CU Commons Citation}

Greg Sergienko, A Body of Sound Practical Common Sense: Law Reform through Lay Judges, Public Choice Theory, and the Transformation of American Law, 41 Am. J. Legal Hist. 175, 224 (1997).

This Article is brought to you for free and open access by the Concordia University School of Law at DigitalCommons@CSP. It has been accepted for inclusion in Concordia University School of Law, Faculty Scholarship by an authorized administrator of DigitalCommons@CSP. For more information, please contact digitalcommons@csp.edu. 


\section{"A Body of Sound Practical Common Sense": Law Reform Through Lay Judges, Public Choice Theory, and the Transformation of American Law}

By Greg Sergienko*

\section{INTRODUCTION}

II. "A BODY OF SOUND PRACTICAL COMMON SENSE"THE CONSTITUTIONAL ORIGINS OF LAY JUDGES

III. "THE LAW ACCORDING TO THE JUSTICE OF EACH CASE"-THE SUCCESSES OF LAY JUDGES

A. "This Court, According to My View, Is Not Strictly a Court of Law"-The Different Perspectives of Lay Judges

B. "Revolutions in Business and Property"The Influence of Lay Judges on Commercial Law

1. "The Interests of a Commercial Community"Financial Improvements and Negotiable Instruments

a) Usury and the Transfer of Negotiable Instruments

b) Rights of Setoff

c) Antecedent Debt and the Rights of Holders in Due Course

d) Acceptance

2. "A Jury, in a Court of Law, Can Mitigate the Damages According to Equity and Good Conscience"Incorporating Commercial Standards into Contract Law

3. "Our Great System of Internal Improvements"-

Modifying Property Rights to Remove Obstacles to Development

C. "Without Regard to the Technical Refinements and Arbitrary and Fictitious Rules"-The Influence of Lay Judges on Procedural Reform

D. "The Common Sense and Common Justice of the Plainest Man"-The Influence of Lay Judges on the Protection of Popular Interests

\footnotetext{
*Visiting Associate Professor of Law, Southern Illinois University. I would like to record here my thanks to the faculty of the University of Richmond, to whom I presented an earlier draft of this paper, W. Hamilton Bryson, Davison Douglas, Gary Leedes, and Michael Wolf, who provided helpful comments on drafts of it, and to Heather Bond, who provided helpful research assistance and comments on multiple drafts.
} 
IV. AN "ANACHRONISM"-THE REJECTION OF LAY APPELLATE JUDGES
A. Burdens on the Legislature and Unfair Surprise to Litigants
B. The Exhaustion of the Possibility of Change
1. The Anti-Democratic Effects of Lay Judges
2. Increased Desire for Precedent
3. The Ability to Make Comprehensive Changes Through Statutory Reform
4. The Preferred Status of Statutory Reform after Swift v Tyson

\section{LESSONS FROM LAY JUDGES}

A. Lay Judges and the Transformation of American Law

B. Lay Judging and Public Choice Theory

\section{CONCLUSION}




\section{INTRODUCTION}

"Ignorance," said Oliver Wendell Holmes, "is the best of law reformers."' And, as poet Thomas Gray wrote, "[W]here ignorance is bliss, 'tis folly to be wise." In an early constitution, New York State followed Gray and anticipated Holmes by having the state's highest court include a predominance of elected state senators to counterbalance the appointed judges. This, the framers of the constitution thought, would reform the law by giving the control of the court to those ignorant of legal technicalities and responsive to democratic elections. In practice, however, it was the elected senators that most favored the elite interests of business people and entrepreneurs, while the appointed judges favored popular interests of borrowers and consumers.

In 1821, New York's radically democratic constitutional convention largely abolished property qualifications for those voting for senators. It also placed New York's thirty-two senators on the highest court, where they greatly outnumbered the six professional judges. Speakers at the convention expressed the belief that senatorial judges would provide democratic control over unelected judges, abolish legal technicalities, and promote justice.

The senators were aware of their law-reforming role under the 1821 constitution and frequently expressed the desire to change the law to promote justice. Paradoxically, however, many of the changes reflected in the new court's decisions abolished protections for the common people. The new decisions limited the power of juries, limited the defenses to claims based on checks or promissory notes, restricted usury statutes, and altered property rights to promote development.

These New York decisions confirm Professor Horwitz' suggestion that American law changed radically in the early 1800 s to favor business and commercial interests at the expense of consumers and other less powerful groups. ${ }^{3}$ However, these new decisions were adopted by the senatorial judges over the objections of their professional colleagues. The senatorial judges succeeded in adopting them only because they greatly outnumbered their professional colleagues. Thus, these decisions do not represent the triumph of elite and business-oriented judges in their struggle against popular control, but the triumph of electoral control over the precedentbound judges.

The constitutional convention of 1846 abolished senatorial judges. Professor Horwitz suggests that because of the success of commercial and mercantile interests, around 1850 judicial decisions became more prece-

1. Oliver Wendell Holmes, Jr., The Common law 64 (Mark DeWolfe Howe ed., Belknap Press 1963) (1881).

2. Ode on a Distant Prospect of Eton College.

3. Morton Horwitz, The Transformation of american Law 1780-1860, at 253-54 (1977). 
dent-bound and formalistic 4 and judges more frequently held statutes unconstitutional. 5 However, the departure of senatorial judges suggests a more persuasive reason for these changes. Decisions became more precedent-bound because the professional judges, continuing as always to adhere to precedent, followed faithfully the new judicial decisions created by the senatorial judges. Decisions more frequently held statutes unconstitutional because the reconstituted court no longer included senators, a majority of whom had necessarily held statutes constitutional when they adopted the laws, and who could not be expected to hold them unconstitutional when they served as judges. 6

Professor Horwitz cites New York as the state "where a strikingly instrumentalist vision of law had appeared the earliest" and as the state where judges "led the way in reversing the earlier support for legislative encouragement of economic growth," by a "dramatic upsurge in judicial review [and invalidation] of legislation."7 New York's history suggests, contrary to Horwitz' thesis, that both these changes resulted primarily from New York's embrace and subsequent rejection of senatorial judges, and that the emerging influence of capitalist interests was only a secondary cause.

In addition to challenging prevailing assumptions about the nature of development, the history of legislative judges has important implications for public policy. The professional judges and the legislative judges had the same cases, heard the same arguments, dealt with the same precedents. The difference in their responses suggests that the removal of popular control over judges 8 often increases their responsiveness to popular interests, because it removes the advantage that organized, special-interest groups have in electing officials. 9 At the same time, the lay judges' adoption of reforms-over the objection of professional judges-that disfa-

4. Id. at 253

5. Id. at 259

6. William G. Bishop \& William H. Attree, Report of the Debates and Proceedings of the Convention for the Revision of the Constitution of the State of New York 371 (Albany: 1846) (statement of Mr. Ruggles, chairman of the committee on the judiciary); 2 J. Hampden Dougherty, The Legal and Judicial History of New York: Constitutional history of New York State from the Colonial Period to the Present Time 173 (1911) (photo. reprint 1983); Nathaniel H. Carter \& William L. Stone, Reports of the Proceedings and Debates of the Convention of 1821, Assembled for the Purpose of Amending the Constitution of the State of New York 45 (Albany: 1821) (Sept. 4, 1821) (statement of Mr. Tallmadge). Carter's report serves as an altemative to Stone's and Carter's report, although originally using their stcnographic reports as one of its sources. See ClARKE, supra at "advertisement" (following title page). Stone and Carter gencrally seems a fuller report, but the sources are different. All citations have been checked against both.

7. HoRwitz, supra note 3, at 259.

8. Judges in New York served during good behavior or until age 60. N.Y. CONST, of 1821 , art. V, $\$ 3$.

9. See Richard A. Posner, Economic analysis of Law 525 (4th ed. 1992) ("consumers fare badly $m$ the legislative process [because $t$ ]hey are too numerous to organize"). 
vored lawyers suggests that judges themselves constituted a special interest, against which lay judges provided an appropriate guard.

\section{II. "A BODY OF SOUND PRACTICAL COMMON SENSE"- THE CONSTITUTIONAL ORIGINS OF LAY JUDGES}

New York's first constitution was closely based on the earlier colonial system of government. The highest court was composed in part of the members of the upper house of the legislature, as was the practice in the British House of Lords. 10 New York's initial Constitution of 1777 also created a "Council of Revision."11 This council had the power to veto laws on grounds of their unconstitutionality or impracticality. $12 \mathrm{We}$ have little direct information on the contemporaneous intent of the New York Constitution of 1777. New York's constitutional drafting process was disordered by the presence of British troops in New York City. ${ }^{3}$ There are no records of any debates. 14

Senators assumed an active role only after the adoption of the constitution of 1821.15 The changed role of the Court of Errors after the convention reflected changes in the constituency that elected the senate as well as increased demands for activism voiced in the convention itself.

Before the constitution of 1821 , the senators were elected by those who had freeholds worth one hundred pounds after deduction of all debt. ${ }^{16}$ Almost all free, adult male citizens could vote for delegates to the convention. 17 This created a democratic convention. As one delegate to

10. N.Y. ConST. of 1777 art. XXXII. In addition to all the senators, this body also included the justices of the supreme court, the chancellor, and "the president of the senate, for the time being." N.Y. ConST. of 1777 art. III. The last clause apparently refers to the person elected president of the senate "pro hac vice," N.Y. CONST. of 1777 art. XXI, although such a person would presumably sit in her capacity as senator.

11. N.Y. CONST. of 1777 art. III.

12. N.Y. CoNST. of 1777 art. III.

13. 2 DOUGHERTY, supra note 6 , at 24 .

14. $I d$. at 25 . The approval was by a vote of 31 to 1 ; the great majority of the delegates being absent on military or other revolutionary business. $I d$. at 26 . There was no ratification by the people. Id.

15. An exceptional earlier case is Yates v. People, 6 Johns. 335 (N.Y. 1810), in which the Court of Errors decided, over the objections of all the professional judges, to review a decision of the supreme court denying habeas corpus. On the merits, the Court of Errors granted the writ of habeas corpus, over the objections of the chancellor, chief justice, and two of the four associate justices. The Court of Errors also overruled a divided supreme court's decisions denying insurance coverage to those whose vessels had been seized by the British as non-neutral. See Goix v. Low, 2 Johns. Cas. 480 (N.Y. 1802) (overruling Ludlow v. Dale, 1 Johns. Cas. 16 (N.Y. Sup. Ct. 1799); Goix v. Low, 1 Johns. Cases 341 (N.Y. Sup. Ct. 1800)). Horwitz describes the Court of Errors' opinion in Goix v. Low as "pathbreaking." Horwitz supra note 3, at 27.

16. N.Y. Const. of 1777 art.X.

17. An act recommending a Convention of the People of This State, ch. XC, $\$ I, ~ V I$, 1821 N.Y. Laws $83,83-84,85$ (1821) ( $\$$ I prescribed the requirements for voting on whether 
the 1821 New York Convention observed, "It is a fact not to be disguised, that a towering majority of this Convention represent the interests, feelings, and views of the friends of democratic government."18 The convention, over the objection of Chancellor Kent and Judge Spencer, ${ }^{19}$ adopted similar standards for voters under the new constitution, allowing those who did not own property to vote for Senators. ${ }^{20}$ Because this greatly liberalized the qualifications of those voting for senators, 21 the convention might well have expected the character of the senators to change.

The demands for democratic control were expressed in the debates and can be inferred from the disparate treatment of the Council of Revision and the lay judges.

The 1821 convention voted unanimously to abolish the Council of Revision. 22 The Judiciary Committee, which was responsible for the abolition of the council, 23 did not provide an official report. However, its chairman stated that the council violated the principle of separation of powers, that senators who had adopted a law might well have prejudged its constitutionality, and that the constitution needed a gubernatorial veto. 24 The unanimity suggests that these reasons were shared. There

to hold a convention and $\S \mathrm{VI}$ applied those requirements to the election of delegates to the convention). The act granted the right to vote to free, adult, male citizens who held freeholds, or rated or paid taxes to the State; or were enrolled in the militia or a volunteer or uniform corps or had been exempted from taxation or militia; or who had been assessed to work on the public roads and highways or who had paid a commutatian. Id. Militiamen and volunteer soldiers could not vote for assemblymen, the representatives in the lower house. N.Y. CONST. of 1777 art. VII.

18. CLARKE, supra note 6 , at 18 (Sept. 5,1821 ) (statement of Mr. Livingston).

19. 2 Dougherty, supra note 6 , at 95 ; John Theodore Horton, James Kent: A Study in CONSERvatism, 1763-1847, at 244 (photo. reprint 1969) (1939).

20. N.Y. CONST. of 1821 art. Il, $\S 1$. In 1826 , the constitution was amended to allow all adult, white, male citizens to vote. N.Y. ConsT. of 1821 amend. I (1826).

21. Voter turn-out does not reliably measure the effect of property restrictions on the number of potential voters, because voting rates fluctuated widely from year to year. Thus, 84,059 people voted for governor in 1816 , only 44,789 in 1818 , and 93,437 in 1820 , although property qualifications remained the same. 2 FrankLin B. Hough, New York Convention Manual: Prepared in Pursuance of Chapters 194 and 458, of the Laws of 1867, Under the Direction of Francis C. Barlow, Secretary of State, Thomas Hillhouse, Comptroller, and John H. Martindale, Attorney-General 417 (Albany: Weed, Parsons 1867).

In $1821,100,490$ adult, male citizens owned freeholds worth enough ( $\$ 250$ or more) after deduction for debts to satisfy the requirements for voting for govemors and senators. Id . at 416. Others entitled to vote only for members of the lower house numbered more than 158,897 , see id., so merely allowing those already entitled to vote for members of the lower house to vote also for senators increased the electorate by more than $150 \%$. This would increase considerably the popular control over the senate.

22. Carter \& Stone, supra note 6, at 47 (Sept. 4, 1821) (statement of Mr. Tallmadge); Clarke, supra note 6, at 14 (Sept. 4, 1821) (statement of Mr. Tallmadge).

23. Carter \& Stone, supra note 6, at 45 (Sept. 4, 1821) (statement of Mr. Tallmadge); ClaRKE, supra note 6, at 14 (Sept. 4, 1821) (statement of Mr. Tallmadge).

24. Carter \& Stone, supra note 6, at 45 (Sept. 4, 1821) (statement of Mr. Tallmadge); ClARKE, supra note 6, at 14 (Sept. 4, 1821) (statement of Mr. Tallmadge). 
were debates on subsidiary points. Many criticized the tribunal for assuming the power to declare laws unwise, as well as unconstitutional, and the delegates argued at length the intent of the original constitution on this point. 25 In addition, Chief Justice Spencer remarked that he disliked serving on the council because the duties were "arduous and painful" and the office of council member was "invidious"; he thought the gubernatorial veto a sufficient substitute. 26 The convention did adopt a gubernatorial veto, modeled after the United States Constitution. 27

Under the new 1821 constitution, the high court, the Court for the Trial of Impeachments and Correction of Errors, less formally called the "Court of Errors," consisted of the President of the Senate, 28 the senators, the chancellor, and the justices of the supreme court.29 New York's judges were appointed by the governor with the advice and consent of the Senate 30 and held office during good behavior or until age 60.31 The chancellors and judges could not hear cases that they had heard in their official roles below. 32

The Court of Errors seemed vulnerable to the same criticism advanced against the Council of Revision. Both required officials from one branch to serve on a body within another branch, thereby violating the principle of separation of powers. Moreover, the senators would have prejudged the constitutionality of laws they had adopted. Indeed, because there were thirty-two senators, ${ }^{33}$ and only four professional judges, ${ }^{34}$ of whom only three could vote on review of any given case, the amateur judges far outweighed the professional judges.

The members of the convention realized these objections, and some

25. CARTER \& StONe, supra note 6, at 49-67 (Sept. 5, 1821) (general debate); Clarke, supra note 6, at 19-23 (Sept. 5, 1821) (statement of Mr. Livingston).

26. Carter \& Stone, supra 6, at 46 (Sept. 4, 1821) (statement of Mr. Spencer); Clarke, supra note 6, at 15 (Sept. 4, 1821) (statement of Mr. Spencer) ("painful, and unenviable"). Chief Justice Spencer also said, "There is reason to fear that the Judiciary, whilst sitting in the Council of Revision, may so far commit themselves upon the construction of a law that when it afterwards comes before them in their judicial capacities, they cannot entirely dislodge the bias they may have previously conceived." CLARKE, supra note 6, at 16 (Sept. 4, 1821) (statement of Mr. Spencer). See also CARTER \& STONE, supra note 6, at 602 (Nov. 2, 1821) (statement of Mr. Clarke).

27. CARTER \& STONE, supra note 6, at 47 (statement of Mr. Jay).

28. The Lieuteriant Governor served as president of the Senate. N.Y. ConsT. of 1821 art. III, § 7. This appears to have been a change from the earlier constitution, which had the "president of the senate, for the time being," in this role. N.Y. CoNST. of 1777 art. XXXII.

29. N.Y. CONST. of 1821 art. V, $§ 1$.

30. N.Y. CONST. of 1821 art. IV, $\$ 7$.

31. N.Y. Const. of 1821 art. V, $\$ 3$.

32. Id. However, the chancellor could hear in the Court for Correction of Errors cases which he had ruled on as a circuit justice. Re Members of the Court of Errors, 6 Wend. 158 (N.Y. 1830).

33. N.Y. CONST. of 1821 art. $1, \S 2$.

34. N.Y. ConsT. of 1821 art. $V, \S 1,4$ (one chancellor, a chief justice, and two justices). 
objected to violating the principle of separation of powers. ${ }^{35}$ Others criticized the number of people on the Court of Errors, saying that the greater the number of judges, the more delay and the less responsibility. 36 These criticisms became two of the main reasons the structure of the Court of Errors was changed in the 1846 Constitution.

Why, then, was there no modification of the Court of Errors in the 1821 convention? No one responded to the complaint that the court would have too many members. Apparently in answer to the criticism that the Senate violated the principle of separation of powers, Mr. Wheaton compared the Senate with the House of Lords, where, he argued, only the law lords voted. 37 However, unlike the House of Lords, the Court of Errors had only judicial functions. If the senators were not going to vote on judicial cases, there was no purpose for their serving on the Court of Errors.

The inadequacy of these explanations suggests that the convention believed the greatest flaw in the existing judicial structure was not separation of powers, but the anti-democratic nature of the Council of Revision. The Court of Errors avoided this defect of the Council of Revision. Although the numerous popularly elected senators violated separation of powers, they also provided democratic control over the courts, which balanced hypertechnicalism in the appointed and tenured lawyer judges. This answered the desire of some delegates for a "tribunal to protect the people from judicial refinement." 38 Another delegate thought the joint representation of senators and judges meant "the judges enjoyed the privilege of hearing able counsel and acquiring new views, while the men of the senate, who were, in most cases, men of plain sense, little versed in the intricacies of law, derived benefit from consulting and advising with the interpreters of equity and law." 39

These comments suggest that lawyers came from a different class than the common people. Lawyers generally came from more educated families than the general populace 40 Although admission to the bar in some jurisdictions could be easy in this period,41 New York required seven years of preparation to be an attorney entitled to practice before the

35. Carter \& Stone, supra note 6 at 503 (Oct. 22, 1821) (statement of Mr. Radcliff).

36. Id. at 528 (statement of Mr. Young).

37. ld. at 504 (statement of Mr. Wheaton). Mr. Wheaton overstated the case. As recently as 1834 , thirteen years after his comments, the House of Lords decided a case without any assistance from lords trained in the law. Thomas Beven, The Appellate Jurisdiction of the House of Lords-Part II, 17 Law Q. Rev. 357, 369 (1901). In O'Connel's Appeal, 11 C1. \& Fin. 155, 421, 8 Eng. Rep. 1061, 1161, 1 Cox Crim. Cas. 413 (1844), issucs of some political controversy led several lords not trained in the law to vote. They were reprimanded by the President of the Council, id. at 421, 8 Eng. Rep. at 1161,1 Cox Crim. Cas. at 550, and when a peer not legally trained did attempt to vote in a later case, Bradlaugh v. Clarke, 8 App. Cas. 354 (H.L. 1883), he was ignored by the Lord Chancellor. Beven, supra, at 370.

38. Id. at 519 (Oct. 22, 1821) (statement of Mr. Root).

39. Id. at 515 (Oct. 22, 1821) (statement of Mr. Van Vechten).

40. See Lawrence Friedman, A History of american law 305-06 (1985).

41. See generally FrIEDMAN, supra note 40, at 317 (half-hour bar examination). 
superior court and an additional three years before one became a "counselor." 42 Statements in New York's next constitutional convention in 1846 , which supported the election of lay judges to the state's highest court, also suggests a perception that non-lawyers would differ from lawyers. 43 Moreover, the frequent turnover could make it difficult to acculturate the senators, preserving, for better or worse, their independence from judicial modes of thinking. ${ }^{44}$ As late as 1833, the chancellor in New York worried about the effect of the frequent turnover of senators on the New York high court. 45

New York's next constitution, framed in 1846 removed the senators from the court and adopted an elected judiciary. 46 The decision in 1846 to abolish the judicial function of senators seems practically unanimous and was the subject of relatively little debate. This absence of debate makes it difficult to determine the terms in which the judicial function of senators was defended and attacked.

The most complete criticism of the court was voiced by Charles Ruggles, Chairman on the Committee of the Judiciary, when he presented the report of the committee. He said, "Dissatisfaction had long existed with regard to the construction of the present court for the correction of errors," and advanced the reasons for its abolition. 47

First, the court, composed as it was of the whole Senate and judges from the supreme court, was too numerous. Fewer members would help ensure that the responsibility of individual members was felt, because it was too much divided among its great number of judges. The lack of responsibility encouraged political decisions and made it difficult to

42. See Friedman, supra note 40, at 316 (citing Alfred Z. Reed, Training for The Public Profession Of The Law 83 (1921)).

43. See infra pp. 13-14 \& notes 54-56.

44. Cf. Charles Rosebury Erdman, Jr., The New Jersey Constitution of 1776, at 12 (1929) (quoting WILLIAM GRIfFITH, EUMENES 98 n.a (1799) (only the governor and two other members "have the least systematic acquaintance with our (the New Jersey] legal code.")). In later years, one researcher found that lawyers constituted from twenty percent to more than a third of the members of upper houses of state legislatures. J. WILLARD HuRST, ThE GROWTH OF AMERICAN LAW 46-49 (1950).

45. “[I]n this court especially, where nearly one fourth of its members are annually changed, and by popular elections, the maxim that it is best to adhere to our decisions...should be permitted to have its full effect." Driggs v. Rockwell, 11 Wend. 504, 507 (1833) (Walworth, C.). The chancellor was referring to the possibility that a quarter of the members might change, not to the actual number of new members. Under the New York Constitution, the senators served for four years, N.Y. CONST. of 1821 art. I, $\$ 2$, and one fourth stood for re-elcction cach year. N.Y. ConsT, of 1821 art. I, § 5. They might, of course, be returned in office; New York had no term limits. However, onc rescarcher says that at least one-third of the members of the upper houses of state legislatures served only one term. Hurst, supra note 44, at 46-49. See generally Belle Zeller, American State LEGISLATURES 70-76 (1954).

46. 2 DOUGHERTY, supra notc 6 , at 181 .

47. BISHOP \& ATTREE, supra note 6, at 371 . Sce also 2 DOUGHERTY, supra note 6, at 171 (describing speech at 1867 convention detailing the reasons for the 1846 change). 
"secur[e] the strict attention of all its members to the elaborate arguments frequently made before it in complicated and difficult cases." 48

Second, "[i]ts connection with the legislative branch of the government was justly regarded by many as a fault in its organization...." 49 This was "particularly so with respect to the decision of all causes in which the constitutionality of an act of the legislature was drawn in question. In all such cases the point in dispute must necessarily have been prejudged in passing the law."50

Third, the earlier constitution diverted the court "from its appropriate duties in the administration of justice, by multifarious subjects on which as senators, its judges have been called to act."51 In particular, Ruggles hoped that separating the court and the legislature would reduce the influence of "the more exciting and distracting scenes of party politics in which the members of the legislature have been continually involved." 52

However, the convention was still interested in maintaining a democratic influence on adjudication. The convention that adopted the 1846 Constitution explained that under the new Constitution, the highest court would be "composed of eight judges_four of whom shall be justices of the supreme court of original jurisdiction and liable to do the duties of a justice of that court in holding circuit courts and terms when not engaged in the court of appeals." 53 Making the judges ride circuit meant that they would "be brought into direct contact with the people and their business,"54 an important democratizing influence. In addition, the constitution allowed for four other slots to which laymen could be elected:

[T] he remaining four judges... shall be elected by the people on a general ballot. This preserves and continues in the court of last resort, a popular and... valuable feature cxisting in the present court. The presence of a portion of laymen in that court, if such should be elected,- of men of extensive general knowledge and sound judgment-not educated to the legal profession, may... correct the tendency which is said to exist in the minds of professional men, to be led away by habits of thought, from the just conclusions of natural reason into the track of technical rules ...55

Election itself was considered a democratizing influence. Some of New York's convention members feared that appointed judges were too often "mere legal monks, always poring over cases and antique tomes of learning." 56 The ultimate replacement of senatorial judges with popularly elected judges in New York was akin to movements in other states, where

\footnotetext{
48. BISHOP \& ATTREE, supra notc 6 , at 371.

49. Id.

50. $l d$

51. Id.

52. Id.

53. Id; N.Y. CONST. of 1846 art. VI, $\$ 2$.

54. Bishop \& ATtREE supra note 6 , at 371.

55. Id.

56. Id. at 636 .
} 
convention members believed that popular election would reduce the aristocratic tendencies of the bench. 57

In practice, election was the only democratizing influence. Nonlawyers did not seem to seek election to the court. Subsequent changes to provide for appointed judges were proposed without considering the possibility that they would keep the people from electing non-lawyer judges. 58 This suggests that the dominance of lawyerjudges was accepted as the norm, despite the hopes expressed in the convention of 1846 that non-lawyers would be elected.

\section{III. "THE LAW ACCORDING TO THE JUSTICE OF EACH CASE"- THE SUCCESSES OF LAY JUDGES}

\section{A. "This Court, According to My View, Is Not Strictly a Court of Law"-The Different Perspectives of Lay Judges}

At least some of the lay judges were conscious of the expanded role that the convention had intended for them. According to one senator, "[A]s this court, according to my view, is not strictly a court of law, I think I am authorized, in deciding questions brought before us for adjudication, to do so in accordance with the impressions on my mind, as to the justice and equity of the matter submitted." 59 Another senator justified his creating the doctrine of constructive eviction on the grounds that the lay senators were to constitute "a body of sound practical common sense, which would not overthrow law, but which would apply the principles and reasons of the law according to the justice of each case, without regard to the technical refinements and arbitrary and fictitious rules, which will always grow upon professional men."60

Not all lay judges shared this cavalier attitude toward precedent. Many of the senators who took an active role in cases were lawyers and therefore might have the same professional habits that the convention of 1821 hoped to overcome in judges. ${ }^{61}$ Moreover, in the same constructive

57. Kermit L. Hall, The Judiciary on Trial: State Constitutional Reform and the Rise of an Elected Judiciary, 1846-1860, 45 Historian 337, 345 (1983). To some extent, the preexisting practice of having elected judges may require re-interpretation of the state's adoption of elective judgeships. Although Missouri in 1832 became the first state to elect all of its judges for limited terms of office, New York's practice of electing 32 senatorial judges means that it was the leader in having a popularly elected judiciary. See Kermit Hall, ThE MaGic Mirror 104 (1989).

58. By $\S 2$ of the amending Judiciary Article of 1869 , the Court of Appeals was made directly elective, composed of seven judges. Section 17 of the article directed the legislature to provide for submitting to the people a proposal for appointive judges. The proposal was rejected.

59. Mclaughlin v. Waite, 5 Wend. 404, 408-09 (N.Y. 1830) (Allen, Sen.).

60. Dyett v. Pendlcton, 8 Cow. 727, 734 (N.Y. 1826).

61. E.g., Colden v. Knickerbacker, 2 Cow. 31, 43 (N.Y. 1823) (Senator Sudam refers to cases that he was involved in as counsel); Wilkes v. Lion, 2 Cow. 333, 394-98 (1823) 
eviction case, another senator took a more restrained view of the court's power.

[T] he plaintiff in crror scemed to appeal to the moral, rather than the municipal law. And if we were to decide this case according to the dictates of morality, we might be disposed to pronounce a judgment in his favor. It is true that the moral law and the law of the land should not be at variance; but if they be so, it is not for us, in our judicial capacity to reconcile them. 62

Other senators had similar objections to the rejection of precedent, especially because judicial decisions retroactively altered the law. Senator Cramer believed that the high court did not have "the power (and by power I mean right) now to question or impeach that judgment rendered by this Court, and founded on the uniform decisions of the Supreme Court during a period of more than seventeen years." 63 If there were any difficulty with the rule, "the legislature are competent to apply a remedy, and will no doubt do it, with a saving as to all rights acquired under those decisions." 64

This case may have been a comparatively easy one in which to uphold precedent. First, Senator Cramer was interpreting wills, in which the reliance on precedent would be great. As the senator observed, "Wills have been made, and estates settled, on the principles of those cases, which have been deemed and treated as the settled law of the land." 65 Second, Senator Cramer was "entirely satisfied as to the soundness and correctness of [the prior] decision" on the merits and its consistency with English and American opinions. 66

On the other hand, the reluctance of some Senators to rule for the tenant in the constructive eviction case of Dyett $v$. Pendleton shows that Senator Cramer was not unique in his caution. In that case, the tenant had moved out because the landlord had been running an illegal brothel in the apartment building, and the landlord could hardly claim reliance on precedent to justify his running an illegal brothel. Anyone who adhered to precedent in such a case would find precedent even more authoritative if a party could show actual reliance on precedent. 67

The argumentative style of senators also seems to differ from that of the professional judges. Senators seemed more likely to emphasize reason

(Senator Cramer catalogued an impressive list of precedents, including decisions from the House of Lords, that it is difficult to imagine a non-lawyer using).

62. Dyett v. Pendleton, 8 Cow. at 739 (emphasis added). See also Rensselaer Glass Factory v. Reid, 6 Cow. 619, 642 (N.Y. 1825).

63. Wilkcs v. Lion, 2 Cow. 333, 394-95 (N.Y. 1823) (Cramer, Sen.) (emphasis in original). New York's supreme court is a lower court, so its decisions did not bind the Court of Errors.

64. Id. at 396.

65. Id. at 394-95.

66. Id. at 394.

67. E.g., Raymond v. Whecler, 9 Cow. 295,298 (N.Y. 1827) ("[I]t is still a very grave question, whether a scttled construction ought to be altered, if it can be adhered to.") (Stebbins, Sen.). 
and justice, even when they also supported their conclusions from precedent. Senator Colden argued from practical problems in discussing the voting rights of the president of the court, saying "that if there may be such occurrences in this court, its organization is very imperfect, and we ought to hesitate before we pronounce that the sages who established it, had so little wisdom as to encumber it with such constitutional provisions as would render it inadequate to the administration of justice."68 Although he discussed the history of the court, he cited no precedent. He used similar reasoning in other cases, giving precedence to examples from the Bible over English cases, ${ }^{69}$ and in another case to practical arguments about "delay, vexation and expense" over other English cases. 70 In another case, he argued primarily from "natural equity," not precedent.71

Thus, the occasional statements made suggesting deference to professional judges must be taken as a courtesy. 72 As the next section shows, the lay judges voted against the wishes of the professional judges many times. Indeed, the lay judges sometimes reversed the lower court opinions of professional judges without even listening to the professional judges, because none participated in the high court.73

\section{B. "Revolutions in Business and Property"- The Influence of Lay Judges on Commercial Law}

Although the amateur judges on the high courts changed a variety of things, the greatest changes occurred in commercial law. One reason for this is that the uneducated and impoverished were unlikely to end up in the Senate in New York. ${ }^{74}$ Because those who ended up on the Senate had to be men of property, whether because of a property qualification or because they received no pay for serving, they were likely to represent moneyed interests. In the northeast, that meant commercial interests.

The changes brought about by the lay judges reflect their interest in three things: ready credit; predictable transactions in a world where commercial dealing was often no longer face-to-face; and development of nat-

68. President of the Bank of Utica v. Wagar, 8 Cow. 398, 400 (1826) (Colden, Sen.).

69. Warren v. Doolittle, 5 Cow. 679, 684 (N.Y. 1825) (Colden, Sen.).

70. Murray v. Coster, 4 Cow. 617, 628-33 (N.Y. 1825) (Colden, Sen.).

71. Mackie v. Caims, 5 Cow. 547, 566 (N.Y. 1825) (Colden, Sen.).

72. Judgment of December 1830, 6 Wend. 158,159 (N.Y.) (serving without any professional judges, Senator Benton said, "The question to be determined is grave and important, and unaided by the suggestions of counsel and by those members of the court who usually participate in the decision of important questions here, I approach the subject with some hesitation, fearing that it may not receive at my hands the examination and illustration its importance requires.").

73. Osgood v. Manhatten Co., 3 Cow. 612 (N.Y. 1824).

74. See N.Y. CONST. of 1777 art. X (senators must be selected by and among freeholders of over one hundred pounds' worth); N.Y. CoNST. of 1821 art. I, $\S 9$ (legislators could not be paid more than three dollars per day); N.Y. ConST. of 1821 art. I, $\$ 2$ (senators had to be freeholders). 
ural resources, which common-law rules of property often obstructed. Where two of these concerns came together, as in the treatment of negotiable instruments, the changes were the most radical.

\section{1. "The Interests of a Commercial Community"- Financial Improvements and Negotiable Instruments}

Because "[c]ash was always in desperately short supply[, e]ntrepreneur, industrialist and smallholder alike needed credit." 75 "Throughout the period," Professor Friedman writes, "There was no satisfactory national currency....Private bank notes constituted the circulating medium of exchange. Credit depended on these bank notes and on personal promissory notes. The law of bills and notes was a vital part of the economic system for this reason." 76

Conflicts between mercantile needs and existing law emerged in several areas. Usury laws intended to protect the improvident from themselves conflicted with merchants' desire to borrow money for business. Existing rules had developed in a world of face-to-face transactions and preserved the rights of those who paid for goods. These rules became problematic in a world where the need for broad circulation of substitutes for currency made it essential to rely on strangers. 77

Because dealing was no longer usually on a face-to-face basis, a person with money did not necessarily know a potential borrower. It therefore became important to be able to rely on documents that became disconnected from the people who made them. The doctrine of negotiable instruments filled this need. A buyer giving a promissory note to a merchant to pay for a load of nails could use defects in the nails as a defense when the merchant sued him for payment on the promissory note. However, because the note was a negotiable instrument, transferring it for value through endorsement to someone who did not know about the defects in the nails would allow the transferee to avoid the defenses of the buyer of the nails. 78 The transferee was willing to give money for the note, because the transferee did not need to know about the transaction between the transferor and the buyer of the nails. Ultimately, the theory was, this benefited the buyer of the nails, by allowing him to pay on credit instead of with cash.

75. FRIEDMAN, supra note 40 , at 269.

76. FRIEDMAN, supra note 40 , at 267

77. As Horwitz observed, "At the heart of all commercial problems lay the question of negotiable instruments and of whether the American legal system could assimilate the principle of negotiability into a conception of contract that had been forged in a precommercial socicty." HoRwITZ, supra note 3, at 212.

78. See generally Frcderick Bcutcl, The Development of State Statutes on Negotiable Paper Prior to the Negotiable Instruments Law, 40 Colum. L. Rfv. 836(1940). 
This concern for the ready availability of money and credit reinforced the desires already present for predictability. Because both these concerns were present in the area of negotiable instruments law, there it was that the lay judges made the greatest changes, repeatedly pressing the claims of commercial interests.

\section{a) Usury and the Transfer of Negotiable Instruments}

The interest of merchants in borrowing money is illustrated by the cases upholding transactions that the professional judges would have overturned as usurious. In Cram v. Hendricks, ${ }^{79} \mathrm{Cram}$ held a note, issued at a non-usurious rate. 80

Cram endorsed the note to a broker, who sold it to Hendricks, the father-in-law of the issuer of the note, three months prior to maturity. 81 This sale took place at a $1 \%$ per month discount, when the statute allowed only $7 \%$ per year. 82 When the issuer did not pay, 83 Hendricks sued Cram. Because the sale to Hendricks had taken place at a discount in excess of the usury rate, the chancellor sought to prohibit Hendricks from recovering anything from Cram. In the chancellor's view, the sale could only have satisfied the usury statute if the payee (Cram) were not guaranteeing payment. 84 Such a case would have involved a "real sale," in which case there is no "equitable right to recover anything... on the endorsement" 85 and Cram could not have been sued. It made no difference that denying a recovery against Cram was unsatisfactory: "as judges, it is our duty to carry into effect every constitutional law passed by the legislature." 86 Senators have "the power elsewhere to apply the constitutional remedy." 87

However, the senators refused to wait until a chance to assume their legislative roles was presented. Senator Allen, unlike the Chancellor, thought that this case did involve a sale of a security. 88 However, he went beyond this disagreement in criticizing the contrary views of some of the professional judges.

He expressly criticized the "strange sentiments" of Chief Justice Taylor in claiming that "the policy of the law against usury is as powerful now... as it was a century ago." 89 "In every country where usury laws

\footnotetext{
79. 7 Wend. 569 (N.Y. 1831).

80. Id. at 570 .

81. Id.

82. Id. at 592 .

83. Id. at 570 .

84. Id. at 574-75.

85. Id. at 575 .

86. Id. at 591 .

87. Id.

88. Id. at 595.

89. Id. at 604 .
} 
have existed, it has been found necessary, for the aid of commerce, to relax this rigidity." 90 Money was necessary to amass wealth, and higher rates of interest were needed to attract capital.91 Finally, Senator Allen appealed to commercial necessity.

These are transactions, however, in which the commercial part of the community are deeply interested. The merchant and trader of ten require facilities, unknown and unrequired by those whose pursuits run in a different channel. The changes and fluctuations in the money market are notorious and frequent, and when this necessary article can be had in no other way, it must be obtained by a sale of property, at whatever price it will bring, whether such property be merchantable or negotiable securities. 92

The alternative, suggested Senator Allen, was to require a merchant to "sacrifice his property under the hammer of the auctioneer," and this had induced the English courts to confine the operation of the usury statutes "within prescribed limits" to avoid "the utter ruin of thousands who were extensively engaged in foreign commerce."93 On only one point did Senator Allen agree with the chancellor-that if there was to be a change in the law, "the proper forum for its amendment is the legislature, and not this court," because of the "ex post facto operation" of judicial decisions. ${ }^{94}$

Senator Beardsley likewise believed that " $\mathrm{t}] \mathrm{he}$ question involved in this controversy is one of vital importance to commercial men." $95 \mathrm{He}$, too, would sustain the transaction because business people needed to be able to raise money by credit.

Every business man knows, that in our commercial cities the credit of merchants is frequently sustained by a sale of notes, as in the present instance. When money is scarce, they raise it more readily and on better terms, by selling their goods on a credit, and endorsing and sending their customers' notes into market, than to dispose of their goods for cash at the auction rooms. 96

Senator Beardsley rejected the applicability of English precedents, saying "[W]e ought to look at the consequences and weigh the reasons for [their decision], before we servilely respond to the decisions of Westminster Hall."97 If, he concluded, transactions such as these were to be overruled, transfers of negotiable instruments would take place only by an outright sale instead of with an endorsement, which everyone agreed would not be within the usury statute. 98 However, the inability of the sell-

90. Id. at 604-05.

91. Id. at 605 .

92. Id. at 609 .

93. Id.

94. Id at 612

95. Id.

96. Id. at 616 .

97. Id. at 628 .

96. Id. at 635 .

97. Id. at 628

98. Id. at 635 
er of the note to endorse it would impair "the value of a bill, in other respects perfectly good," 99 because the person who bought the note could only have recourse against the person who originally made it.

Senator Maynard, like the others, emphasized that "[t]he interests of a commercial community require that [promissory] notes should be the subject of sale and transfer." 100 He reviewed the history of usury laws around the world and concluded that these statutes may well have had their basis in the "morbid cravings"101 of anti-Semitic prejudice. Whatever may have been their basis, they "came into existence before commerce had produced revolutions in business and property, and in the social condition,"102 "[b]efore distant communities had learnt to increase their comforts by an interchange of commodities; when manufacturers, as a great and distinct occupation, were unknown; the avocations of men were few and simple, and a vast proportion of the aggregate amount of property consisted of real estate." 103 Under these new circumstances, the old rules, fashioned before the law of negotiable instruments, 104 could no longer be followed.

Senator Sherman finished off the delivering of opinions by agreeing with the chancellor. He relied on the clear language of the statute, which made void any security on which an interest rate higher than the seven percent set by statute, and on the experience of Alabama, which had abolished its usury laws and as a result had experienced notes charging 30,60, 70,80 , or in one case even 120 percent. 105 However, his was a dissenting vote. Although seven senators joined the chancellor, sixteen senators disagreed and favored allowing the transaction. 106

\section{b) Rights of Setoff}

Some of the changes in negotiable instruments law involved issues peculiar to New York, because they turned on New York statutes. In Bridge v. Johnson 107 the high court had to interpret a New York statute allowing a defendant to setoff a counterclaim against the plaintiff to

99. Id.

100. Id.

101. Id.

102. $I d$.

103. Id.

104. Id.

105. Id. at 661-63.

106. Although the lay judges were cager to limit usury restrictions in voluntary transactions, many opposed charging an cxccutor compound interest on moncy taken from the estatc. See De Peyster v. Clarkson, 2 Wend. 77 (N.Y. 1828) (Sutherland, J., joined by ten senators, affirmed the decision of the chancellor charging interest; nine senators wanted to overrule the decisions that allowed the interest to compound).

107. 5 Wend. 342 (N.Y. 1830 ). 
reduce the plaintiff's ultimate recovery. 108 Under the statute, the defendant claimed that he could setoff a note that he held, because the payee of a note was the assignor of the plaintiff in the case. The trial court denied the claim of setoff, and the chancellor wrote an opinion to affirm. ${ }^{109}$

However, the majority of the lay judges opposed the limited construction of the statute. Senator Beardsley wrote an opinion to reverse because of the "equity of the statute."110 Senator Tallmadge also wrote an opinion to reverse, arguing that reading the statute broadly would prevent a "multiplicity of suits" 11 and that former decisions had not settled the construction of this statute. 112

The vote divided equally, 113 and the court decided that this meant that the judgment would be affirmed, but that the decision would not bind the high court.114 In subsequent litigation on the same issue, the professional judges and the chancellor adhered to their previous opinions on the merits.115 The chancellor also wrote against the advisability of changing the law:

The maxim, Stare decisis, et non quieta movere, is to a certain extent applicable to the decisions of all courts, particularly of the higher courts of law and equity. But in this court especially, where nearly onc fourth of its members are annually changed, and by popular elections, the maxim that it is best to adhere to our decisions, and not to disturb questions which have once been put at rest here, should be permitted to have its full effect. 116

The lay judges, however, rejected this view. Their votes carried the issue, and the court adopted the reasoning of the senators in the prior case, thereby setting a precedent for broadly construing the statute on setoffs.

108. An Act for the Amendment of the Law and the Better Advancement of Justice, 1813 N.Y. Laws, 36th Sess., ch. LVI, $\S 1$, at 515, 515-16 (April 5, 1813) (codified at 2 N.Y. Rev. Stat. pt. III, ch. VI, tit. 2, $\$ 18-25$, at 354-55 (1829)).

109. 5 Wend. at 343-44 (Woodworth, J.) (statement of reasons given in lower court); id. at 346 (Walworth, C.).

110. Id. at 355 (Beardsley, Sen.). The statute allowed the defendant to recover against the plaintiff the amount by which the setoff exceeded the plaintiff's claim. Id at 354 . Such a provision could not fairly be applied against a plaintiff who was the assignee of the person against whom the setoff was asserted, because such a plaintiff would end up indebted to someone without notice of the claim. Id. at 358. The professional judges argued from this that the statute could not be applied against anyone but the party in interest, and that the statute therefore did not apply to this case. Id. at 343-44 (Woodworth, J.); id. at 346 (Walworth, C.). However, Senator Beardsley thought the equity of the statute would setoff all of the plaintiff's claim without allowing a recovery against the plaintiff for the excess. $I d$. at 355 .

111. Id. at 352 (Tallmadge, Sen.).

112. Id. at 360 .

113. Id. at 371 .

114. Id. at 372 (Senator Oliver, President of the Senate pro tem).

115. Driggs v. Rockwell, 11 Wend. 504 (N.Y. 1833)

116. Id. at 507 (Walworth, C.). On the merits, Walworth believed that the right of setoff should extend to "the real plaintiff for whose benefit the suit was brought, although he was not the nominal plaintiff on record." Id. at 508 (emphasis in original). He would have ruled in favor of the right of setoff on the facts of the case. $I d$. 
Senator Beardsley adopted the view of Senator Stebbins in Wheeler $v$. Raymond to the effect that a setoff could "be maintained against the party in interest," even if not a party in the record. 117 He "would go further in upholding setoffs, and thus avoiding circuity and multiplicity of actions, than the rule laid down by Senator Stebbins. In the case of a promissory note, transferred after due and thus dishonored on its face, and where, according to well settled and indisputable authorities, it is taken wholly on the credit of the assignor, I would not only allow a set-off against the party to the record and the party in interest, but against every party through whose hands it has thus passe."118

Beardsley was unrelenting in his criticism of the opposing view. He described the supreme court's decision by Justice Woodworth as "a novel exposition of the statute, altogether at variance with the former decisions of the same court; that it was a perfect surprise to the great body of the profession; subverted the equity of the statute; impaired its usefulness; made it in a great measure a dead letter; tended to increase litigation instead of preventing it, as was the object of the statute; opened the door to atrocious frauds; and led to an immediate enactment by the legislature to bring back the law to what it was before."119 The court voted seventeen to three to reverse, almost universally rejecting the decision of the professional judges.

Although this opinion rejected the views of the professional justices, their subsequent decisions in the trial courts followed the precedent it set One of these justices adopted the broad rule of setoff, saying that the rule of the supreme court in Bridge v. Johnson,120 "may, I think, be considered as overthrown." 121 Other professional justices in the lower court construed the court's prior decisions narrowly to avoid a conflict with the decisions of the Court of Errors. Smith v. Van Loan 122 refused to rely on an earlier case denying a setoff, because " $[\mathrm{t}]$ he very brief and imperfect statement of facts in the report of the case is calculated to give the decision a wider influence than was intended by the court." 123 In the case on which the Smith court refused to rely, the payee had promised the note would be returned to the maker, but the payee instead fraudulently transferred for the payment of an antecedent debt at a substantial discount.124 The court distinguished the prior case as denying holder in due course sta-

117. Id. at 510 (Beardsley, Sen.) (citing Whecler v. Raymond, 9 Cow. 295 (N.Y. 1827) (Stcbbins, Sen.)).

118. Id. at 510 .

119. Id.

120. 6 Cow. 693 (N.Y. Sup. Ct. 1826), aff d by an equally divided court, 5 Wend. 342 (N.Y, 1830).

121. Miner v. Hoyt, 4 Hill 193, 197 (N.Y. Sup. Ct. 1843).

122. Wend. 659, 661 (N.Y. Sup. Ct. 1837).

123. Id. at 662 (citing Rosa v. Brotherson, 10 Wend. 85 (N.Y. Sup. Ct. 1833)).

124. Id. 
tus only because of the fraudulent transfer, not because of the antecedent debt. 125

\section{c) Antecedent Debt and the Rights of Holders in Due Course}

The lay judges drastically expanded the doctrine of the holder in due course. This doctrine allows someone who takes a negotiable instrument, such as a promissory note or check, to collect on the instrument against the person who made it, even if that person would have had a valid defense to a suit brought by the person to whom she first gave the note. To qualify as a holder in due course, the person taking the note had to give value for the note.

One of the first instances in which the lay judges distinguished themselves from their professional colleagues was in Bridge v. Johnson, 126 which interpreted the setoff statute discussed immediately above. The lay judges in that case not only rejected the professional judges' interpretation of the statute, they also attacked language in the professional judges' decision limiting the ability of those who took notes to become holders in due course. Senator Beardsley commented on the language of one of the professional judges, who had said that "an actual transfer of a note before it is due and in actual payment of a pre-existing debt, is not such a bona fide transfer as will protect the holder against the equities of the maker of the note."' 27 Although Senator Beardsley was willing to concede the point in that case, he continued, "I do not refer to this decision as assenting to its correctness, as I am by no means prepared to affirm that a transfer of negotiable paper before it is due, in payment and discharge of a pre-existing debt (not a pledge for a debt) is not as bona fide a transaction as a transfer for money or goods; and I shall not be surprised if that question is brought before this court for review at some future period." 128

Although the issue was not in fact revisited by the Court of Errors, Senator Beardsley's essential prediction, that holder in due course status would extend to those who took an instrument in payment of a pre-existing debt, was borne out by events. In 1842, in Swift v. Tyson, 129 a case arising out of New York, the Supreme Court of the United States held that someone taking an instrument for a preexisting debt could become a holder in due course. In the next case to reach the Court of Errors, Stalker $v$. $M$ 'Donald, 130 Chancellor Walworth perceived the petitioners to be seek-

125. Id. at 661-62.

126. 5 Wend. 342 (N.Y. 1830).

127. Driggs v. Rockwell, 11 Wend. 504, 509 (N.Y. 1833) (Beardsley, Sen.) (citing Rosa v. Brotherson, 10 Wend. 85, 86 (N.Y. Sup. Ct. 1833)).

128. Id.

129. 41 U.S. (16 Pet.) 1 (1842), overruled on other grounds, Erie R.R. v. Tompkins, 304 U.S. 64 (1938).

130. 6 Hill 93, 97 (N.Y. 1843). 
ing "to induce this court to overrule its decision... and to make our decision conform to the opinion of Mr. Justice Story in the recent case of Swift v. Tyson." 131 The chancellor argued that "the principle established in Coddington v. Bay" was that "merely receiving [the instrument] in security or payment of an antecedent debt" was insufficient to qualify as a holder in due course. 132

However, his senatorial colleagues interpreted Coddington v. Bay much more narrowly. In Coddington, the notes were taken solely "as a guaranty or indemnity." 133 Senator Lott interpreted Coddington as turning on the distinction between taking a note as payment for antecedent debt and taking it for security. He quoted Woodworth's opinion in Coddington which said, "[S]omething must have been paid in money or property, or some existing debt satisfied, or some new responsibility incurred in consequence of the transfer; this would be paying value, and making out a consideration within the reason and meaning of the rule."134 Senator Lott went on to quote Chief Justice Spencer's decision in Coddington, "I understand, by the usual course of trade, not that the holder shall receive the bills or notes thus obtained, as securities for antecedent debts, but that he shall take them in his business, and as payment for a debt contracted at the time."135 Because, Lott concluded, the jury in this case had found the persons taking the notes not to have taken any consideration, but merely having obtained them "as a mere pledge or collateral security," he found this case within Coddington, even as narrowly read. 136

Following the senator's lead, lower court justices began to read Coddington as applying only to cases where a negotiable instrument was taken as security, and not where it was taken for an antecedent debt. In Scott v. Betts, 137 Justice Beardsley 138 held that if the transfer of the check paid a pre-existing debt, the check is to be deemed as purchased for value. He wrote, "[l]t is, however true that it has been adjudged in this state that one who receives negotiable paper in payment of a preexisting debt is not a holder for value. But this principle is virtually overruled by the later cases in this court, and is opposed to the general current of authority on

131. Id. at 95 (citing 41 U.S. (16 Pet.) 1 (1842)).

132. Id. at 99 (citing Coddington v. Bay, 20 Johns. 637 (N.Y. 1822)).

133. Coddington v. Bay, 20 Johns. 637, 644 (N.Y. 1822) (Woodworth, J.). Even in Coddington, where the professional judges, Platt and Spencer, concurred in the decision affirming the chancellor, $i d$. at 648 , seven senators dissented without an opinion having been recorded for any of them. Id. at 652 . This senatorial dissent may reflect opposition to restrictions on the acquisition of holder-in-due-course status even on those facts.

134. Id. at 112 (quoting Coddington, 20 Johns. at 646) (Woodworth, J.).

135. Id. (quoting Coddington, 20 Johns. at 646) (Spencer, C.J.).

136. Id. at 113 (referring to id. at 94).

137. Hill \& Den. 363,370 (N.Y. Sup. Ct. 1844).

138. Samuel Beardsley, a different person from the former Senator Levi Beardsley, see 10 Wend., frontispiece. 
the subject."139 Subsequent cases reached the same result. 140

This distinction between transferring a negotiable instrument as a security and transferring it as payment for an antecedent debt is nebulous at best. ${ }^{141}$ It will rarely be in the interests of the parties to the transfer to deny that the transfer was for value. The transferee will want to establish a transfer for value to recover from the maker of the note or the drawer of the check. The transferor will not oppose this, because if the transferee does not recover against the maker or drawer, the transferee will recover from the transferor. So completely does the sale transaction dominate the problem that the now-reduced principle of Coddington seems not to have been applied since Stalker.

\section{d) Acceptance}

One way in which to encourage people to take a negotiable instrument instead of cash was by having an "acceptance" on the instrument. An instrument is accepted when the person whom a check, draft, or bill of exchange directs to pay money promises to honor the instrument by signing it. 142 In the absence of an acceptance, the person on whom the instrument is drawn has no obligation to pay it. 143 This increases the desirability of the instrument by providing notice that a presumably solvent person has agreed to pay the check, just as a bank's certification increases the desirability of a check.

The lay judges developed the doctrine of "virtual acceptance." Under this doctrine, "an unconditional promise in writing made within a reasonable time before or after the date of the bill and describing the same in terms not to be mistaken," operates as "a virtual acceptance thereof in favor of any person to whom such promise has been shown, and who has received the bill for a valuable consideration on the strength of such promise."144

139. Hill \& Den. at $370-71$ (citations omitted).

140. Farrington v. Frankfort Bank, 24 Bar. 555,563 (N.Y. Sup. Ct. 1857); Farrington v. Frankfort Bank, 31 Bar. 183, 189 (N.Y. Sup. Ct. 1857); Cardwell v. Hicks, 37 Bar. 458, 463. 64 (N.Y. Sup. C'. 1862).

141. Cf. U.C.C. $\$ 9-102 \&$ official comment (1994) (trcating sales of accounts and chattel paper as transfers for security because of the "difficult problems of distinguishing between transactions intended for security and those not so intended").

142. E.g., U.C.C. \$ 3-410(1) (1994).

143. U.C.C. $\$ 3-409(1) \&$ comment 2 (1994); N.I.L. $\$ 189$ (1896).

144. Grecle v. Parker, 5 Wend. 414, 416 (N.Y. 1830). The doctrine of "virtual acceptance" was adopted in the early Negotiable Instruments Law. N.I.L. $\$ 134$ (1896). The Uniform Commercial Code abolished it as an "anomalous exception to the policy that no person is liable on an instrument unless his signature appears on it," and because "[g]ood commercial and banking practice does not sanction acceptance by any separate writing because of the dangers and uncertainties arising when it becomes separated from the draft." U.C.C. $\$ 3-410$ (1) official comment, purposes of change, I 3 (1994). 
The chancellor, the sole professional judge participating, believed that the person suing on the acceptance should introduce the letter to which the acceptance was a response or prove its contents by oral evidence if the letter were unavailable. ${ }^{145}$ However, the lay judges held that the burden of showing limitations on the acceptance was on the acceptor, not on the party relying on the acceptance, so that an apparently absolute virtual acceptance governed.146 To justify this result, Senator Allen argued that making an acceptance binding according to its terms, even when it may have been in response to a more limited letter, "prevents frauds, and accommodates the mercantile transactions of the country." 147 This argument persuaded his colleagues, who voted fourteen to eight in favor of adopting the doctrine of "virtual acceptance."

\section{2. "A Jury, in a Court of Law, Can Mitigate the Damages According to Equity and Good Conscience"- Incorporating Commercial Standards into Contract Law}

Traditionally, the chancellor had the discretion to withhold an order enforcing a contract if the plaintiff's conduct had been inequitable. Instead, the chancellor ordered the plaintiff to pursue his legal rights before a jury, who could then give the plaintiff the relief they thought fit, because "a jury, in a Court of law, can mitigate the damages according to equity and good conscience." 148

Commercial standards required predictability about the enforcement of contracts. Against the wishes of all the professional judges, the lay judges held that specific performance should be awarded, rather than damages, rejecting the professional judges' argument that juries could take into account the equities of the case and reduce a recovery to an appropriate amount. 149

Commercial standards also required predictability about who owned property. With an increase in the number of transactions conducted with strangers, people needed to be able to rely on people they had known only briefly or not at all. Merchants' expectations about the solvency of someone apparently in the possession of goods would be disappointed if secret interests to the goods made them unavailable to satisfy claims.

In Abraham v. Plestoro, the court had to decide claims to goods claimed by both their possessor, who had arrived in New York after his property had been assigned by an English court to the bankruptcy trustee, and the bankruptcy trustee himself, who arrived in New York later. ${ }^{150}$ The

145. Id. at 418.

146. Greele v. Parker, 5 Wend. 414 (N.Y. 1830).

147. Id. at 420 . See also id. at 422.

148. Seymour v. Delancey, 3 Cow. 445, 518 (N.Y. 1824) (Savage, C.J.).

149. Id.

150. Abraham v. Plestoro, 3 Wend. 538 (N.Y. 1829). 
lay judges upheld the rights of the apparent owner to goods in his possession, even though under English law the goods belonged to the bankruptcy trustee, because a transfer under English law could not be validly applied to creditors in New York. 151 The professional judges in both the trial and appellate courts would have applied English law and the English judicial decision, which gave title to control of the goods to someone who arrived after the goods had been in the possession of their apparent owner. 152

Likewise, in a case where the professional judges were split, the lay judges held that someone who had received goods pursuant to a condition had title to the goods. 153 In a third case, the professional judges would have allowed a debtor to convey his property to one of his creditors, getting back $\$ 2000$ per year, but leaving his other creditors with nothing. The lay judges, after a nod towards the importance of precedent, rejected the advice of their professional brothers and voted eighteen to six to invalidate the conveyance, thereby expanding the law of fraudulent conveyances. 154

In some instances, the claims of predictability cut both ways. Where a plaintiff had agreed with the captain for the delivery of a package, and the package was lost, the court had to determine whether the contract made the owner or the master of the vessel responsible, or just the captain. 155 The company had prohibited the captain from taking the package, but had not put up any signs warning people about the limitations on the captain's authority. 156 Those sending packages would favor making the company responsible for the conduct of its apparently authorized captain. The company would favor avoiding being bound by activities that it had expressly prohibited. The professional judges ruled in favor of the shipper, both in the trial court and in the Court of Errors. 157 However, the majority of lay judges overruled them. 158

The efforts by lay judges also extended to the incorporation of commercial custom into the interpretation of contracts. In Dow v. Whetten, 159 the issue was the definition of "proceeds" in a contract of insurance, and one party tried to introduce the application of insurance to show the inten-

151. Id. at 559 (Maynard, Sen.); id. at 560 (Oliver, Sen.).

152. Id. at 540, 546. The vote was seventeen to four in favor of reversing the chancellor"'s injunction in favor of the bankruptcy trustce. Id. at 572 .

153. Furniss v. Hone, 8 Wend. 247 (N.Y. 1831). Judge Nelson in the Court of Errors favored the party in possession; the chancellor had ruled in favor of the deliverer of the goods. The lay judges split seventeen to four in favor of the party in possession.

154. Mackic v. Cairns, 5 Cow. 547 (N.Y. 1825).

155. Sewall v. Allen, 6 Wend. 335 (N.Y. 1830).

156. Id. at 356 (McLean, Sen.) (prohibition); id. at 360 (Oliver, Scn.) (absence of public notice).

157. Id. at 354.

158. See id. at 365.

159. 8 Wend. 160 (N.Y. 1831). 
tion of the parties. The supreme court ruled that in the supreme court an application could be used only to show a misrepresentation and rejected evidence introduced to show a customary commercial understanding of the policy. 160 The Court of Errors agreed that the application could not show the definition of the policy. However, it held that commercial usage could be used to construe a contract, ${ }^{161}$ the chancellor and the lay judges combining to overturn the professional judge in the supreme court. 162

\section{3. "Our Great System of Internal Improvements"- Modifying Property Rights to Remove Obstacles to Development}

In New York in the 1810 s and 1820 s, the great economic fact of life was the construction and use of the Erie canal.163 Other improvements in transportation were required, too, including lesser canals, turnpikes, or bridges. 164 These developments created new legal problems.

Although the court expressed great concern lest it interfere with the rights of property, its decisions limited property rights where those rights would prevent economic development. Under the English common law, those holding land the boundaries of which were defined by a river or stream owned to the middle of the river or stream bed. The adoption of this rule in New York might have greatly burdened economic development, by requiring canal builders to compensate those who owned the river or stream bed.

The Court of Errors had to decide what to do with the common law in Canal Commissioners v. People ex rel. Tibbitts. 165 Tibbitts sued when his waterfall was destroyed when the canal commissioners raised the water level with a dam.166 Tibbitts argued that the patent granting him land, which specified a navigable fresh water river as a boundary, included the river bed, so that he took the river bed up through the middle of the river to the exclusion of the state.

Tibbitts' view was consistent with the common law, and the professional judges in the supreme court upheld his claim in both hearings. 167 In

160. Id. at 163 .

161. Id. at 169.

162. Seventeen members of court voted to reverse; five senators voted to affirm. Id. at 174.

163. See generally Carter Goodrich, Canals and American Economic DeVtelopment 209 (1961); Carter Goodrich, Promotion of American Canals and Railroads, 18001890 , at $52-55$ (1960). For a brief mention 5 of the legal effect of the canals, see, e.g., FrIEDMAN, supra note 40, at 181; HoRwITZ, supra note 3 at 68.

164. FRIEDMAN, supra note 40, at 180.

165. 5 Wend. 423 (N.Y. 1830).

166. Id. at 457 (Beardsley, Sen.).

167. Tibbitts' claim was heard twice. On the first appeal, the Court of Errors reversed, 20-5. The reasons for the disposition are unclear, because the votes are collected only on the basis of affirmance and reversal, and there were both procedural and substantive grounds for reversal. See id. at 474 (Tallmadge, Sen.) (arguing that pleading was defective, but leave to replead should be granted). 
both hearings in the Court of Errors, the professional chancellor wrote an opinion in favor of affirming the supreme court. He said that the state had the power to declare waters navigable and to regulate "so as to preserve this right of public navigation," but did not have the power of "making waters navigable which are not so by nature, or of appropriating such waters to the public use," without paying compensation. 168

Senator Beardsley argued for reversal. Although he said that he generally deferred to precedent 169 and conceded that the supreme court had "frequently recognized the rule of the common law as applicable to our rivers," he refused to follow those cases because the state was not a party to them. ${ }^{170}$ His reason for rejecting the common law was that "[r]ules of law should be adapted not only to the moral but to the physical condition of the country."171 Senator Benton likewise argued for reversal. Like Senator Beardsley, he cited and rejected these prior cases and Sir Matthew Hale's statements of the English common law. 172

On rehearing, after the technical issue had been disposed of, Samuel Beardsley, 173 the Attorney General of the State of New York argued for the canal appraisers, and B.F. Butler, the Attorney General of the United States, argued for Tibbitts. The judges largely adhered to their previous positions. The supreme court once again ruled in favor of the landowners, and the chancellor once again favored affirmance.174 Once again, the Court of Errors as a whole adopted the opinion of the lay judges. Although Senator Beardsley 175 noted the problems resulting from disregarding individual rights, 176 he again argued for reversal, because of the need for promoting "our great system of internal improvements."177 The court reversed, thirteen to eleven, adhering to its initial position. This cleared the way for the Erie Canal.

In Hart v. Mayor of Albany, 178 the Court of Errors again dealt with conflicting claims to a river, this time between someone who had erected a floating storehouse on a river, and the City of Albany, which considered

168. Id at 448 .

169. Cf. McLaughlin v. Waite, 5 Wend. 404,412 (N.Y. 1830) (Beardsley, Sen.) (upholding the common-law distinction between moveables and intangibles as to the rights of a finder).

170. Wend. at 463 (Beardsley, Sen.).

171. Id. at 463 .

172. Id. at 467.

173. The Attorney General was not the same person as Levi Beardsley, the senator writing in McLaughlin v. Waite, 5 Wend. 404, 412. (N.Y. 1830), see supra p. 38 \& note 169, who continued on this court, see 17 Wend. (no page, after copyright date), or John Beardsley, also a senator at this time, see $i d$.

174. Canal Appraisers v. People ex ref. Tibbitts, 17 Wend. 571 (N.Y. 1830).

175. The opinion does not state which Senator Beardsley expressed these opinions, but both joined in voting for reversal. See id. at 630 .

176. $I d$. at 606.

177. Id. at 606. Senator Tracy argued for reversal. Id. at 620 .

178. 9 Wend. 571 (N.Y. 1832). 
it to be a public nuisance. The owner of the storehouse sought an injunction against the destruction or sale of his property. In the lower court, the Chancellor dissolved an injunction on the grounds that trespass provided an adequate remedy at law, and in the Court of Errors, the professional Justice Sutherland wrote an opinion to affirm the decree of the chancellor on the theory that there was an adequate remedy at law. ${ }^{179}$ However, Senator Allen wrote an opinion to affirm on the broader grounds that the City of Albany had power to remedy the nuisance. 180 Senator Edmonds wrote an opinion to affirm, adopting Justice Allen's position. ${ }^{181}$ Although it could be argued that the decision only stands for the narrow holding of the professional judges, 182 the Court of Appeals subsequently adopted the position of the lay judges that the private storehouse in the river was a nuisance and that the city had the power to remedy it. 183

In one area, the exclusivity of franchises, the lay judges did not entirely favor innovation. Early cases in New York and elsewhere had generally held that the state's allowing one company to incorporate for a specific purpose precluded a similar grant to subsequent companies. Thus, Chancellor Kent had ruled that the incorporation of one turnpike company impliedly precluded the grant of incorporation to a competing company. 184 Kent had adopted this position because, "If such a contrivance as this case presents, is to be tolerated, all our statute privileges of the like kind, on which millions have been expended, would be rendered of little value and the moneys have been laid out in vain."185 Kent later granted a turnpike corporation an injunction against a private group that built a bridge that provided an alternative to the turnpike. 186

Many of the lay judges supported Kent's position, even though the professional judges began to narrow Kent's precedents. In Lansing $v$. Smith, 187 the commissioners of the land office had granted the plaintiff the right to erect a wharf, and he sued when the commissioners subsequently granted another company the right to build a pier in front of the plaintiff's, greatly reducing the value of the plaintiff's wharf. The plaintiff argued that this violated the federal Constitution's prohibition of state laws impairing the obligation of contracts and the state constitution's prohibition against taking private property for public use without just compensation. The supreme court ruled that the former grant by the commissioners of the land office did not preclude the legislature from making a

179. Id. at 585 .

180. Id. at 598 .

181. Id. at 609.

182. Senator Tracy also wrote an opinion to affirm on the grounds that there was an adequate remedy at law. Id. at 610 .

183. Lawton v. Stecle, 119 N.Y. 226, 239, 23 N.E. 878, 880, 880-81 (1890).

184. Croton Turnpike Co. v. Ryder, 1 Johns. Ch. 611 (N.Y. Ch. 1815).

185. Id. at 616.

186. Newburgh Turnpike Co. v. Miller, 5 Johns. Ch. 101, 111-12 (N.Y. Ch. 1821).

187. 4 Wend. 2 (N.Y. 1829). 
public improvement for the benefit of commerce, contradicting, Chancellor Kent's position.

The new chancellor wrote an opinion to affirm the supreme court, because under the common law rule, "the king as parens patria owned the soil under all the waters of all navigable rivers or arms of the sea where the tide regularly ebbs and flows," and the state succeeded to these rights. 188 The chancellor reasoned that because the state owned the soil under the riverbed, it could make a new grant to build a pier. However, the distinction that this reasoning implied was tenuous, because the implication of exclusivity that Kent had applied to the state's power to grant an incorporation could easily be applied to the state's ownership of the land under navigable waters.

The objection to the opinion of the professional judges came from Senator S. Allen, who wrote an opinion to reverse the supreme court, arguing that the act is "very unjust and oppressive," and six other lay judges joined him in dissenting from the chancellor and the thirteen lay judges who formed the majority. 189 It remained for a later case, Auburn \& Cato Plan Road Co. v. Douglas, 190 decided after the Constitution of 1846 had in effect abolished lay judges, for the Court of Appeals expressly to criticize Chancellor Kent's ruling. 191 That decision relied on decisions from other states and on the United States Supreme Court's decision in the Charles River Bridge Case, which upheld Massachusetts' power to grant a right to build a second bridge across the Charles River. ${ }^{192}$

\section{C. "Without Regard to the Technical Refinements and Arbitrary and Fictitious Rules"- The Influence of Lay Judges on Procedural Reform}

Procedural law is one area where one would expect the senators to be successful in changing the law. After all, where else can tricky legal technicalities succeed in preventing a hearing on the merits?

In some respects, these expectations were fulfilled. Moreover, in some of these areas the change threatened the interests of the lawyers, so the non-lawyer senators provided a corrective to the special interests of the professional judges. For example, statutes in New York would occasionally provide that a plaintiff, if unsuccessful, would have to pay double costs to a party, such as a sheriff, that the legislature believed was likely to be harassed. The "general practice" in New York's trial courts was to pay the double costs to the attorney, not the party. ${ }^{193}$ When one of these

188. Id. at 20 .

189. Id. at 27.

190. 9 N.Y. 444 (1854).

191. Id. at $450-51$.

192. Id. at $452-53$ (citing Charles River Bridge v. Warren Bridge, 36 U.S. (11 Pet.) 420 (1837)).

193. McFarland v. Crary, 6 Wend. 297, 311 (N.Y. 1830) (Tallmadge, Sen.). 
cases went up to the Court of Errors, that court held that the costs were to be awarded to the party, with the senators overruling the opinion of the professional judges on the court. 194

In other respects, the conflicts between lay and professional judges over procedure resulted in few clear-cut victories for either side. In Newman v. Van Antwerp, 195 twelve senators outvoted ten senators and the chancellor, limiting the power of the Court of Errors to award costs, because of the apparent absence of any statutory authority.

On three other issues, the lay senators represented a significant minority, but were outvoted. In Murray $v$. Coster, the trial court denied a plea raising the statute of limitations and required the defendant to file an answer. 196 The honest answer admitted the existence of the contract, and under the usual rules, such an admission barred raising the statute.197 The chancellor, one of the professional judges, and some senators adhered to precedent, barring the defendant from raising the statute of limitations, even on appeal. The dissenters criticized the majority for violating the statute of limitations. 198

In Fulton Bank v. Beach, an answer was put in and filed purporting to be the joint and several answer of 12 defendants, but one defendant did not sign that answer and filed a separate answer, raising the defense of usury. 199 The chancellor held that the answer was irregular and struck it, barring the defendant from raising the defense of usury, raised only in his answer. 200 The professional judges all voted to affirm the opinion of the chancellor. 201 The majority of senators agreed with them, although seven dissented on the grounds that the chancellor's rules should not be applied to promote injustice.202

In Colden v. Knickerbacker, 203 eight lay judges would have approved

194. McFarland v. Crary, 6 Wcnd. 297 (N.Y. 1830). The Court of Errors rejected the claim for costs by a vote of eleven to six. Some favored affirming solely because the person seeking costs had not paid for the defense. See id. at 303 (Beardsley, Sen.); id. at 311, 316 (Tallmadge, Sen.). One senator decided the case on a wholly separate issue. Id. at 308 (Benson, Sen.). Thus, although the vote count does not show why scnators cast their votes, at least eight favored awarding costs to the party, and at most cight favored awarding them to the attorney. Subsequent cases have held that the decision "did not proceed on the ground that the attorneys were entitled to the money; but on the ground that it belonged to one Billings, who had indemnified the officer, and carried on the defence" Whecler $v$. McFarland, 2 Denio 183, 184 (N.Y. Sup. Ct. 1846). Accord Calkins v. Williams, 5 How. Pr. 393, 393 (N.Y. Sup. Ct. 1850).

195. 4 Cow. 711 (N.Y. 1825).

196. 4 Cow. 617,629 (N.Y. 1825) (Colden, Scn.).

197. Id. at 627 .

198. Id. at 644 (Crary, Sen.).

199. 6 Wend. 36, 61 (N.Y. 1830) (Oliver, Sen.)

200. Id.

201. Id. at 41-44 (Savage, C.J.).

202. Id. at 61 (Oliver, Sen.); id. at 44-60 (Masher, Sen.); id. at 62 (vote count).

203. 2 Cow. 31 (1823). 
a change to allow those against whom a default judgment had been taken to appeal to challenge error appearing on the face of the record.204 They were outvoted by twelve professional and lay colleagues.

Many senators also attempted to abolish legal distinctions that they did not believe had merit. In McLaughlin v. Waite, 205 the plaintiff found a lottery ticket. The defendant, the issuer of the lottery ticket, advertised for the true owner, who never claimed the prize. The lower court ruled that because the ticket was a chose in action (a right to sue for money or property), the finder could not collect the prize; if the ticket had been considered ordinary personal property, the finder could collect the prize if the true owner could not be found.206 The chancellor wrote an opinion to affirm on that basis. 207 Seven senators attempted to depart from the common-law distinction, 208 one stating that the court, being "not strictly a court of law" 209 could resolve things according "to the justice and equity of the matter.210 However, they were outvoted by a majority of their colleagues. 211

\section{D. "The Common Sense and Common Justice of the Plainest Man"- The Influence of Lay Judges on the Protection of Popular Interests}

In addition to addressing some purely procedural rules, the Court of Errors protected substantive interests by simplifying rules to allow claims to be treated as offsets. The most extreme version of simplification was the battle fought in commercial law over negotiability and the right of setoffs in negotiable instruments. ${ }^{212}$ However, the court simplified procedural rules in several other instances to protect the interests of buyers of products and renters of houses.

For example, in Reab v. McAlister, the trial court excluded evidence that the product the defendant had purchased from the plaintiff failed to satisfy the defendant's descriptions. 213 The trial court would have required the buyer to pursue separate claim for fraudulent misrepresentation or breach of warranty.214 The Court of Errors reversed, allowing in the evi-

204. 2 Cow. at 54 (Sudam, Sen.).

205. 5 Wend. 404 (N.Y. 1830).

206. Id. at 406.

207. Id.

208. Id. at 410 (Allen, Sen.).

209. Id. at 408.

210. Id. at 409.

211. One of the colleagues, Senator Beardsley, likewise distinguished between moveables and choses. Id. at 412 .

212. See supra § III.B.1, pp. 188-197 ("The Interests of a Commercial Community"Financial Improvements and Negotiable Instruments).

213. 8 Wend. 109 (N.Y. 1831).

214. Id. at 118 (Allen, Sen.). 
dence to show a setoff. As one senator explained, combining proceedings would avoid "vexation and expense" and "useless litigation." 215

In Dyett $v$. Pendleton, a lessee and his family left their apartment because they were disturbed by the landlord's using the building for prostitution and the associated "noise and riotous proceedings." 216 The lessee pled eviction, 217 and the trial court denied relief on the grounds that the lessee's remedy was to complain to the police, who would then presumably punish the landlord so that the offense would be abandoned.218 Others suggested that the lessee's true remedy was by a separate civil suit.219 The Court of Errors reversed. Many in the Court of Errors rejected reliance on precedent, turning "not to the statute law, nor to the common law, but to the great principles of morality, on which both are founded"220 and explaining why "common sense and common justice"221 and the "plainest dictates of justice" 222 required reversal. However, they also argued that independent suits were an inadequate remedy. 223

In other cases, the Court of Errors applied accepted law to limit people's ability to take advantage of others. This was most pronounced in cases of people not dealing with one another at arms' length. Thus, in Hall $v$. Perkins, the chancellor required an uncle, who was an advocate in the justices' courts, to pay his nephew original claim of at least $\$ 500$, although he had persuaded his nephew to accept a conveyance of land worth less than $\$ 240$ instead.224 The chief justice, joined by the professional justices and the entire Court of Errors, wrote an opinion affirming, stating that this case "address[ed] itself to the common sense and common justice of the plainest man, and seems to require no legal learning to decide it" 225 and that no authority "can be necessary beyond an appeal to the moral sense." 226

These three cases are counter-currents to the tendency to limit inquiry into the sufficiency of consideration. As Horwitz notes, some cases limited inquiry into consideration. 227 However, these cases can easi-

215. Id. at 119 .

216. 8 Cow. 727,736 (N.Y. 1826).

217. Id.

218. Id.

219. Id. at 740 (Colden, Sen.) ("civil suit or public prosecution"); id. at 744 (Allen, Sen.) (suit on the case for damages).

220. Id. at 738 (Crary, Sen.).

221. Id. at 734 (Spencer, Sen.).

222. Id. at 735 .

223. Id. at 734 .

224. 3 Wend. 626 (N.Y. 1829).

225. Id. at 629 (Savage, C.J.).

226. Id. at 630 .

227. See Horwitz supra note 3, at 180 \& n.105 (citing Seymour v. Delancey, 3 Cow. 445,533 (N.Y. 1824)). 
ly be read too broadly. In Seymour v. Delancey, 228 the principal case on which Horwitz relies to establish the doctrine that the courts will not inquire into the adequacy of the consideration, the writer for the majority said, "I cannot assent to the doctrine, that inadequacy of price may, of itself and without fraud or other ingredient, be sufficient to stay the application of the power of a Court of Chancery, to enforce a specific performance of a private contract to sell land." 229 This limitation to land was not incidental. The majority remarked on the "great difference of opinion" 230 that usually exists about the value of land and the absence in the country and country villages of any "settled criterion by which property can be estimated," 231 it being "not uncommon" for someone to hold land hoping for a higher price until the sheriff has to sell it to satisfy the owner's debts. 232 Indeed, the majority opinion limited the case still further, saying, "There is another circumstance which has considerable weight with me; and it is that this contract is for the exchange of real property... It is a transaction wholly different; ...from a cash sale."233 Finally, the majority stated that in a case for specific performance, "the contract must be founded on adequate consideration" 234 and allowed that "[t]here may be such inadequacy of price as, of itself, to be an evidence of fraud."135

In Seymour v. Delancey, the case refusing to scrutinize the fairness of the bargain, the lay judges outvoted the professional judges, who would have refused to enforce the contract. In the other three cases, a majority of both the lay and professional judges favored the result. Because both Dyett v. Pendleton and Reab v. McAlister changed prior law by (respectively) creating the doctrine of constructive eviction and allowing what would formerly have required a separate case to be treated as a counterclaim, precedent did not prevent the professional judges from accomplishing some procedural reforms by themselves.

\section{AN "ANACHRONISM"- THE REJECTION OF LAY APPELLATE JUDGES}

The large number of cases in which the lay judges altered the results that the professional judges would otherwise have reached demonstrates the enormous influence of the lay judges.

If anything, counting the cases in which the votes of the lay judges

228. 3 Cow. 445 (N.Y.1824).

229. Id. at 532-33 (Sudam, Scn.) (cmphasis supplied).

230. Id. at 531.

231. Id.

232. Id.

233. Id. at 534 .

234. Id. at 526.

235. $I d$. at 533. See also id. at 529 . 
caused the court to reach a result different from that which the professional judges would have reached understates the influence of the lay judges. First, the opinions of the senators might have convinced the judges that their initial beliefs were wrong, causing the judges to alter their views before they expressed them. Second, the senators might have learned something in their judicial capacity that would cause them to change the law legislatively. In Cram v. Hendricks, 236 a senator alluded to changes "in the statutes regarding double costs, in relation to the presumption of law relative to wills, and so as to set offs."237 In Bridge v. Johnson,238 a senator also discussed the legislative changes to the statute of set off.

Nor do these successes seem freakish. The experience of the United Kingdom's House of Lords provides a parallel that demonstrates the potential of lay judges for improving the law. The House of Lords, against the criticism of all the professional judges, permitted a remainder to vest in an unborn child. 239 A later writer speaks of this decision as being "good sense," 240 and it was even extended.24I Later, the Lords avoided "technical reasoning" to achieve "substantial justice... though by a rough road" 242 by relying on extrinsic evidence showing that the wishes of the testator were satisfied, though it meant ignoring an explicit condition precedent. 243

Despite these successes, the use of lay judges declined. Why? Several theories have been advanced in constitutional conventions and elsewhere, including burdens on legislators, unfair surprise through the use of the legislators' subjective intent, and separation of powers. However, most of the theories fit poorly with the facts of lay adjudication.

\section{A. Burdens on the Legislature and Unfair Surprise to Litigants}

Lon Fuller claimed that the procedural burdens on the legislature caused the decline of legislative judges. 244 However, no one in the constitutional conventions expressed the view that having legislators involved in the courts burdened the legislators. 245 Nor do these debates support

236. 7 Wend. 569 (N.Y. 1831).

237. Id. at 634 .

238. 5 Wend. 342,359 (N.Y. 1830 ).

239. Reeve v. Long, I Salk. 227, 91 Eng. Rep. 202 (1695). The House of Lords' decision was "against the opinion of all the judges, who were much dissatisfied with the reversal" of the lower courts' opinions. 1 Salk. at 228, 91 Eng. Rep. 202.

240. Beven, supra note 37, at 366 .

241. The Posthumous Children Act, 1698, 10 Will., ch. 22.

242. Beven, supra note 37 , at 367 .

243. Bertie v. Falkland, 1 Colles 10, 1 Eng. Rep. 155; 3 Ch. Cas. 129, 22 Eng. Rep. 1008 (1697).

244. Lon Fuller, The Anatomy of the Law 16-17 (1968).

245. One delegate mentioned the fear of the diversion "from its [apparently, the court's] appropriate duties in the administration of justice," but that seemed to result from "the morc 
Fuller's belief that legislators might unfairly surprise the public about the meaning of a statute by relying on their private, concealed intent about the meaning of a statute. 246 Indeed, no legislative judges referred to their special knowledge of the drafting history of the statute. This reflects the predominance of common-law over statutory adjudication at this time. Moreover, a difference between judicial and legislative interpretation does not necessarily imply that the legislators were unfairly surprising litigants. In some instances, such as the professional judge's preference for awarding double costs to attorneys instead of clients,247 it was the judiciary and not the legislature that was out of step with the terms of the statute and its popular understanding. 248

Some problems came from conflicts in the roles of legislators and judges. Critics always cited the principle of separation of power against legislative judges.

However, despite frequent references to separation of powers, the specific concern with legislative tyranny underlying the principle of separation of powers was seldom mentioned. No one complained that legislators used their retroactive judicial powers to surprise individuals unfairly. Nor did anyone point to statutes that had been sustained, but should have been invalidated. Indeed, one delegate to the 1846 convention said of the Court of Errors that it, "though considered an anomaly by all, had, somehow or other, most generally contrived to do justice without violating law, and had, until mischiefs had latterly crept in, given general satisfaction to the community." 249 Even then, the mischiefs were left unspecified. As a result, one suspects that "separation of powers" was more a slogan than a shorthand formula for a coherent political philosophy. This is borne out by New York's 1821 convention, which abolished the Council of Revision because it violated "separation of powers," but which also gave a judicial role to senators, in violation of the doctrine of separation of powers.

Moreover, separation of powers could only be a partial explanation for the end of lay appellate judging. The conflicts resulting from joint service on the courts and in the legislative branch can be abolished by having lay judges that are not part of the legislature. This would also have answered arguments based on the supposed burdens on the legislators and the risk of unfair surprise from secret legislative history. The New Jersey Constitution of 1844 adopted lay, non-legislative judges.250 New York could have fol-

cxciting and distracting scencs of party politics," mentioned later in the same sentence, not overwork. BISHOP \& ATTREE, supra note 6, at 371.

246. FULLER, supra note 244, at 18.

247. McFarland v. Crary, 6 Wend. 297 (N.Y. 1830).

248. See Owen Fiss, Objectivity and Interpretation, 34 StAN. L. ReV. 739 (1982).

249. S. Crosswell \& R. Sutton, Debates and Proceedings in the New York State Convention, for the Revision of THE Constitution 447 (Albany, N.Y.: 1846) (August 11, 1846) (statement of Mr. Jordan).

250. N.J. CoNST. of 1844 art. VI, § II, II 1. 
lowed the recent precedent of its neighbor. The failure of New York to do so suggests the end of lay judging resulted from other reasons.

\section{B. The Exhaustion of the Possibility of Change}

Lay judging may have become less attractive because of the judges' success in altering the law and because the possibility of legal change through the judicial process may have been exhausted. First, because the lay judges' alterations in the law often promoted business interests at the expense of the common people, the lay judges could no longer expect support from pro-democratic interests. Second, the lay judges had always been nervous about tinkering with precedent, and their success in changing many parts of the law reduced the need to tamper with precedent any further. Moreover, comprehensive change could more easily be accomplished through statutory reform. Finally, the United Supreme Court's decision not to follow state judicial decisions in interpreting the common law, which shortly preceded the adoption of the 1846 Constitution in New York, made statutory change preferable.

\section{The Anti-Democratic Effects of Lay Judges}

The lay judges were put on the court to protect "democratic" interests. As one delegate to the 1821 New York Convention observed, "It is a fact not to be disguised, that a towering majority of this Convention represent the interests, feelings, and views of the friends of democratic government."251 However, the definition of "democratic" interests was more ambiguous than the statement of this delegate might suggest. If promoting democracy meant simplifying the law by doing away with legalistic distinctions and procedural impediments to the hearing of cases on the merits, then lay judges were an unambiguous, although incomplete, success. 252

The lay judges did more than this, though. Their decisions also did much to satisfy the needs of merchants for predictable law and a substitute for currency. Some of these decisions may have harmed the interests of those dealing with merchants. For example, requiring the chancellor to grant specific performance even to someone who had behaved inequitably or sold defective goods eliminated the power of the jury to reduce the damages awarded. 253 This provided predictability, but also rewarded one guilty of over-reaching conduct. Limiting defenses based on usury and increasing the negotiability of instruments provided an alternative to currency. However, it also prevented the buyer of defective goods from using those defects to defend against a claim brought by the holder of the note

251. ClARKE, supra note 6, at 18 (Sept. 5, 1821) (statement of Mr. Livingston).

252. See supra pp. 45-49.

253. See Horwitz supra note 3 , at $165 \&$ nn.23-25. 
that the buyer had given for the goods. 254

These changes in negotiable instruments law were reached by lay judges over the objection of their professional colleagues. Thus, the "democratic" legislative judges were less concerned for the interests of consumers than were the chancellor and the professional judges. This record may have discouraged those interested in protecting consumers from campaigning for the continuation of legislative judges.

\section{Increased Desire for Precedent}

Mercantile and commercial interests in the early 1800 s needed two inconsistent things from the judiciary. One the one hand, they needed change for the sake of modernization. On the other hand, they needed stability for the sake of predictability. Thus, one senator wrote that a decision overruling precedent would upset people's wills. In the senator's view, the problem was not primarily the loss to those who had planned their wills in reliance on precedent: "These evils, however, might be transient; and affecting a few hundreds only, or possibly a few thousand individuals, [and] would probably terminate and be forgotten with the present generation." 255 The true concern, "a more momentous and ruinous consequence, would be the total insecurity of property, and all personal rights." 256

This conflict was exacerbated by the structure of the court. The high degree of popular control over the court, with almost one quarter of its members having to stand for re-election every year, meant that the court had to follow precedent scrupulously or face possible chaos.

The judges were aware of these conflicts. In one case, involving what we would now call a fraudulent conveyance, 257 the professional judges favored validating the conveyance. In opposition to this, Senator Colden first remarked,

If there be such a thing as natural equity; if we may ever appeal to those perceptions of right and wrong which are independent of all learning, it seems to me, that we may do so on this occasion; and can not hesitate to decide that such a disposition of property is invalid. 258

But then Colden reversed his willingness to rely on natural equity: "If this Court has heretofore determined that an assignment like those now under consideration, made under the same circumstances, may be maintained, we ought to consider this as the established law..." 259

Colden deferred to precedent because of the high degree of popular control over the court:

254. See id. at $220,242-43$.

255. Wilkes v. Lion, 2 Cow. 333, 395 (N.Y. 1823) (Cramer, Sen.).

256. Id.

257. Mackie v. Cairns, 5 Cow. 547 (N.Y. 1825).

258. Id. at 564 (Colden, Sen.).

259. Id. at 567-68. 
The members of this Court are in part annually changed; and if those who compose it at any time should fecl themselves unrestrained by the determinations of their predecessors, the rights of things and persons might vary as often as the Court was in session; and we should be in that condition which onc of our oldest writers says marks a miserable people, "where the laws are vague and uncertain.260

Senator Colden closed his discussion of precedent with an expression of deference in his judicial role to his capacity as legislator-" "If the law, as settled by this Court, be inconvenient or wrong, it must be for the legislature to change it."261

Colden's reluctance to prohibit fraudulent attempts to conceal property because they "may have been made in accordance with judgments of this Court" greatly limited the scope of innovation that the Court of Appeals could have made. That suggested a preference for statutory change, especially because the changes the lay judges had already made reduced the need for further judicial change.

\section{The Ability to Make Comprehensive Changes Through Statutory Reform}

Statutory reform had special attractions in the middle 1840 s. The constitutional convention identified procedural rules as the source of many of the problems in New York's administration of justice.262 However, many of these rules were difficult to change through commonlaw adjudication, because few attorneys or clients would ignore precedent and risk dismissal of a claim or defense. Ruling against someone who observed existing rules, merely because the court decided to change those rules, would be harsh.

Other rules had a statutory or constitutional basis, and so could not be altered by the courts. For example, the courts in New York were divided into two main categories, law courts and equity courts. These courts provided different sorts of relief-law courts could not grant injunctions, and equity courts could act only on the person of the defendants, not against their assets-and no court could provide both sorts of relief. Worse still, these courts used conflicting rules of law. For example, in Dow v. Whetten, the Court of Errors ruled that in a court of law, an application for insurance could be used only to show a misrepresentation, but in a court of equity, it could be used to correct the policy. 263 Who won the lawsuit could turn on these evidentiary issues, and therefore on the court in which the action was filed. Abolishing these conflicting rules and allowing litigants to obtain complete relief would have required merging the law and equity courts, which was beyond the courts' power.

260. Id. at 568. Five senators joined Colden in this opinion. Id. at 568 .

261. Id.

262. BISHOP \& ATTREE, supra note 6, at 371.

263. 8 Wend. 160,169 (N.Y. 1831 ). 
Instead, New York merged law and equity through a process of constitutional revision and statutory change. The New York Constitution of 1846, which abolished legislative judges, also created the Code Commissioners, who were charged with rewriting the state's procedural rules. 264 Their work culminated in the Field Code of Civil Procedure. Because of the difficulties in carrying out this reform through precedent, "the cornerstone of the whole Field codification structure was the Code of Civil Procedure."265 This code merged law and equity and simplified pleading, thereby addressing in a statute what could not conveniently have been done with retroactive precedent. 266

\section{The Preferred Status of Statutory Reform after Swift v. Tyson}

An additional reason for abolishing the lay judges was that judicial alteration of precedent became less effective in accomplishing change. This ineffectiveness resulted from the Supreme Court's decision in Swift $v$. Tyson that the federal courts would apply their own version of "the general principles and doctrines of commercial jurisprudence," even though a state's judicial decisions would require a different result. ${ }^{267}$ In Swift itself, the United States Supreme Court disregarded the decision of the New York Supreme Court.268

Under $S$ wift, the law applied in a specific case would depend on whether suit was filed in state or federal court. Swift meant the effective end of commercial law reform through the judicial process, because the federal courts would disregard the decisions of the New York courts. Thus, judicial change in the law in the state courts could not guarantee that the law applied to a transaction would change. Even worse, judicial modification of established rules could create a conflict with the federal courts' decisions, making the law difficult to predict. This was especially serious in commercial law and negotiable instruments law, because disputes in these areas were likely to involve citizens from different states, giving one party access to a federal court. Under the threat of Swift, New York state courts felt "compel[led]" to overrule decisions that conflicted with those of the United States Supreme Court, because of "the great importance of the question to a commercial people, especially the importance of uniformity between the courts of the State and Union, in the rules

264. N.Y. Const. of 1846 art. VI, $\S 24$ (creating Commissioners of Practice and Pleading).

265. Alison Reppy, The Field Codification Concept, in DAVID DUDLEY FIELD: Centenary EsSays 17, 49 17, 49 (Alison Reppy ed., 1949). Field believed that procedural reform was the "most important question" that could be presented to the legislature. DAUN Van Ee, David Dudley Field and the Reconstruction of the Law 28, 29 \& n.48 (1986).

266. See generally EE, supra note 265; FRIEDMAN, supra note 40, at 391-94.

267. 41 U.S. (16 Pet.) 1 (1842).

268. See id. at 17 (citing Rosa v. Brotherson, 10 Wend. 85 (N.Y. 1833)). 
of law regulating commercial transactions."269

$S$ wift did allow for statutory reform, because it required federal courts to follow state statutory law. In Swift, the Supreme Court interpreted a federal statute requiring the federal court to apply "the laws of the several states except where the Constitution, treaties, or statutes of the United States shall otherwise require." 270 The Court held that "the laws of the several states" meant only their statutory law, the "rules and enactments promulgated by their legislative authority," not their judicial decisions. 271 Thus, Swift created an incentive for the states to carry out their law reform through statutes, which the federal courts would follow, rather than through adjudication, which the federal courts would ignore.

Swift was decided in 1842; in 1846, New York's new constitution abolished legislative judges. The same constitution established a commission to report on ways of codifying substantive law, with any changes they deemed proper. 272

\section{LESSONS FROM LAY JUDGES}

\section{A. Lay Judges and the Transformation of American Law}

Professor Horwitz has argued that the American law was transformed twice in the late eighteenth and the nineteenth century. ${ }^{273}$ First, American courts adopted an instrumental conception of law and re-shaped the law to fit the purposes of the mercantile economy.274 Second, American courts in the mid-nineteenth century, having changed the law to promote the interests of commerce and industry, sought to put those changes beyond the reach of the political process. To do this, they adopt-

269. Dorr v. New Jersey Navigation Co., 6 N.Y. Super. Ct. Rep. (4 Sand.) 136, 141-2 $(1850)$.

270. The Rules of Decision Act, Judiciary Act of $1789, \S 34,1$ Stat. 92, cited in 41 U.S. (16 Pet.) at 18, codified as amended, 28 U.S.C. $\$ 1652$.

271. 41 U.S. (16 Pet.) at 18.

272. N.Y. CONST. of 1846 art. I, $\$ 17$ (creating Commissioners of the Code). The commissioners were "to reduce into a written and systematic code the whole body of the law of this state, or so much and such parts thereof as to the said commissioners shall seem practical and expedient. And the said commissioners shall specify such alterations and amendments therein as they shall decm proper." Id.

273. HorwITz, supra note 3. For comments on Horwitz' thesis, sec Eugene Genovese, Book Review, 91 HARV. L. REv. 726 (1978); Wythe Holt, Morton Horwitz and the Transformation of American Legal History, 23 WM. \& MARY L. REV. 666 (1982); A.W.B. Simpson, The Horwitz Thesis and the History of Contracts, 46 U. CHI. L. REv. 533 (1979); Harry Scheiber, Private Rights and the Rule of Law in American Legal History, 72 CAL. L. REV. 220 (1984); Gary Schwartz, Tort Law and the Economy in Nineteenth Century America: A Reinterpretation, 90 YALE L.J. 1717 (1981); Peter Karsten, “Bottomed on Justice": A Reappraisal of Critical Legal Studies Scholarship Concerning Breaches of Labor Contracts by Quitting or Firing in Britain and the U.S., 1630-1880, 34 AM. J. LEG. HIST. 213 (1990).

274. HORWITZ, supra note 3, at 253-54. 
ed a "formalist" and deductive model of the law to make it seem apolitical.275 Where formalism failed to insulate the law from legislative change, the courts were increasingly ready to hold statutes unconstitutional.276

The New York cases provide much to support the thesis about the change in American law. The law in New York changed radically and generally in the direction that Horwitz describes. Of course, not all changes promoted the interests of merchants or business people at the expense of farmers, consumers, and laborers. For example, allowing counterclaims for breaches of warranties by description avoided a multiplicity of suits, but also provided the equivalent of the "fair price" doctrine with the added benefit of allowing the purchaser of the goods to recover damages in excess of the purchase price. 277 The broad interpretation of the statute on setoffs promoted negotiability, 278 perhaps at the expense of buyers of goods, but it also provided non-merchant defendants with a chance to object to claims against them for the price of goods purchased from merchants. In other cases, the court focused on the interests of merchants among themselves, not on merchant-purchaser relationships. For example, the leading case on usury had two merchants as parties, and the senators speaking in the case all emphasized the need of merchants to borrow money. 279 These cases, however, are exceptional; many of the points in which the law changed seemed to reflect transfers of wealth, at least in the first instance, from consumers and others to merchants.

However, the Horwitz thesis ignores the issue of who changed the law. The great majority of the New York cases on which he relies were decided by legislative judges over the objection of their purely judicial colleagues. 280 These include decisions altering property rights so as to eliminate claims to streambeds 281 ; allowing municipalities to destroy floating storehouses 282 ; requiring the chancellor to grant specific performance, thereby preventing the jury from reducing the damages recovered by someone guilty of over-reaching conduct 233 ; and limiting usury defenses and increasing the negotiability of instruments. 284 Because it was the legislative judges who changed the law, the New York cases are inconsistent with the opposition between judicial and legislative control

275. Id. at 259.

276. Id.

277. Reab v. McAlister, 8 Wend. 109,119 (N.Y. 1831).

278. Bridge v. Johnson, 5 Wend. 342 (N.Y. 1830).

279. Cram v. Hendricks, 7 Wend. 569 (N.Y. 1831).

280. If the changes adopted by the legislative judges were incfficient subsidies, as Horwitz suggests, sce HoRwITZ, supra note 3, at 99-101, the empirical difference in behavior between legislative and judicial judges supports Posner's argument that Iegislative activity tends to be less efficient than judicial activity. See POSNER, supra note $9, \S 19.2$, at 523 .

281. See Horwitz, supra note 3, at 67.

282. See id. at 77.

283. See id. at $165 \&$ nn.23-25.

284. See id. at 220, 242-43. 
that Horwitz finds in the transformation and with Horwitz' suggestion that developers sought to avoid "the more politically volatile legislatures." 285

Horwitz also argues that once the transformation of American law had been accomplished, the rhetoric of formalism and the science of law arose to shield law from popular interests. 286 The decisions of senatorial judges present two difficulties for this argument.

First, they show that formalism 287 and the scientific approach to law are not inherently conservative. Thus, in inventing the doctrine of constructive eviction, one of New York's senators remarked, "The whole science of law consists in the application of a few simple principles to the 'affairs and bosoms of men." 288 Another senator said, "We regard cases as containing the evidence of the law, as evincing the rule of decision; and they are consulted to ascertain the principle on which that rule is founded." 289

These views cannot easily be distinguished from Langdell's famous dictum, "Law, considered as a science, consists of certain principles or doctrines. To have such a mastery of these as to be able to apply them with constant facility and certainty to the ever-tangled skein of human affairs, is what constitutes a true lawyer... Moreover, the number of fundamental legal doctrines is much less than is commonly supposed."290

The true difference between Langdell and law reformers was not their view that the law could be deduced from basic premises, but the premises from which they deduced the law. The reformers saw the law as an expression of morality. Thus, the same person who held that " $[t]$ he whole science of law consists in the application of a few simple principles" continued in the same opinion to state that he resolved the case by "resort not to the statute law, nor to the common law, but to the great principles of morality, on which both are founded."291 This relation between a scientific law and morality could not "separate politics from law, subjectivity from objectivity, and laymen's reasoning from professional reasoning," 292 which Horwitz sees as the function of a scientific law. For Langdell, on the other hand, morality was not a source for judicial decisions. He wrote, in response to a protest that justice was not well served by a particular rule, "The true answer to this is that it is irrelevant, but

285. Id. at 254 .

286. Id. at 253-66.

287. Horwitz defines formalizing as "reclassifying [a legal] problem into a supposedly nonpolitical doctrinal category." Id. at 261.

288. Dyett v. Pendleton, 8 Cow. 727, 737 (N.Y. 1826) (Crary, Sen.).

289. Id. at 732.

290. Christopher Columbus langdell, a Selection of Cases on the law of Contracts with ummyo eopc Covred by the CaSes viii (2d ed. 1879). See also Arthur E. Sutherland, The Law at Harvard 175 (1967).

291. Dyett v. Pendleton, 8 Cow. at 738 (Crary, Sen.).

292. Horwitz, supra note 3, at 257. 
..."293 As Holmes observed in a review of Langdell's book "the language is only incidental, but it reveals a mode of thought which becomes conspicuous." 294

The second and more fundamental difficulty with the argument that formalism was concocted to conceal the effects of prior instrumentalist decisions is that the courts' use of formalism exhibits greater internal consistency than Horwitz might suggest. The professional judges tended to adhere to precedent and write formalist opinions, and the lay judges tended to promote mercantile interests with instrumentalist opinions. In the early 1800 s, the professional judges were consistently outvoted by their more numerous lay colleagues. The New York Constitution of 1846 abolished the lay judges. The professional judges displayed the same adherence to precedent that they always had, but, because they were no longer outvoted by their colleagues, they retained the law in roughly its 1846 form.

The change in constitutional structure also explains the increase in the rate with which courts held statutes unconstitutional. Horwitz, who cites only the New York cases for his conclusion that the rate with which courts held statutes unconstitutional rose sharply, argues that this change occurred because of the "sharply antilegislative trend that began to take hold in the courts." 295 Although Horwitz has cited Corwin's data296 in arguing that the increasing willingness of courts to overturn laws resulted from the increasing desire to "check the overly political uses of the law,"297 neither he nor Corwin address the possibility that the change in the court's composition contributed to this change in outcome.298 In fact, Corwin summarizes and Horwitz reports the data by decades, 299 which obscures the dramatic effect of the mid-decade abolition of legislative judges.

Breaking the data down by year reveals a different picture. In the 1840 s before the 1846 constitutional convention took effect, the state courts held statutes unconstitutional in eight specific decisions. ${ }^{300}$ Two of these decisions set aside the same act, 301 so only seven specific acts were

293. LANGDELL,' supra note 290, at 995-96.

294. Oliver Wendell Holmes, Jr., Book Notice, 14 AM. L. Rev. 233, 234 (1880).

295. HoRwITz, supra note 3, at 260.

296. Edward S. Corwin, The Extension of Judicial Review in New York: 1783-1905, 15 MICH. L. Rev. 281 (1917).

297. HoRwITZ, supra note 3 , at 259.

298. Id. at 259 \& n.6. Horwitz cites only Corwin's article for his conclusion. Id.

299. See Corwin, supra note 296, at 285; HORwITZ, supra note 3, at 289 . The effect of the mid-decade switch tends to undermine Corwin's thesis, that the greatest cause of the expansion of judicial review was not the "constitution of 1846 , but... conflict between the conservative principles of the courts and the reform tendencies of legislation." Corwin, supra note 300 , at 285 .

300. Corwin, supra note 296 , at 306 .

301. Id. at 283 n. 6 . 
set aside, less than one for each of the seven-and-one-half years in which the old constitution was in effect. ${ }^{302}$ Six specific acts were set aside in the first full session year of the courts after the 1846 constitution took effect, almost as many acts as were set aside in the preceding part of the decade, a rate more than six times higher. 303 Indeed, before the 1846 constitutional convention, few litigants bothered to challenge statutes before the New York courts, but "[a]fter 1846 such cases become too numerous to list."304

The gradual evolution of legal doctrine or gradual economic growth does not explain the sudden increase in the frequency with which statutes were overruled. The removal of legislative judges does. This removal eliminated those who had prejudged that the statute was constitutional when they adopted it in their legislative capacity, thereby increasing the chance that the statute would be held constitutional when they ruled on it in their judicial capacities. 305 Those at the convention specifically intended to remove the chance of senatorial prejudgment when they modified the court. 306

In suggesting that the abolition of legislative judges better explains the change in reasoning styles and the greater willingness of the courts to rule statutes unconstitutional, I do not mean to suggest that economic and political considerations were irrelevant. However, the disparity between the results of the senatorial judges and the professional judges suggests that the senatorial judges changed the law in a way that economic factors do not explain. The influence of senatorial judges therefore cannot be disregarded as a mere "superstructure." The failure to consider the role of such institutional structures suggests that many aspects of legal history in the early 1800 s may need to be revisited. 307

302. The new constitution took effect on the first Monday in July 1847. N.Y. Const. of 1846 art XI, $\$ 4$.

303. Corwin, supra note 300 , at 306 .

304. Id. at $283 \mathrm{n} .7$. In fact, the presence of senators on the high court led even the professional judges to conclude that the statutes had to be constitutional. In Livingston $v$. Van Ingen, Chief Justice Kent said that an act's being adopted after the issue of unconstitutionality became known for similar, prior acts is "equivalent to a declaratory opinion of high authority, that the former laws were valid and constitutional." 9 Johns. 506, 572 (N.Y. 1812). In the same case, Justice Thompson observed, "It certainly affords a strong and powerful argument in favour of the constitutionality of a law that it has passed not only that branch of the legislature which constitutes the greater portion of our court of dernier resort, but also the council of revision..." Id. at 564 .

305. The threat of prejudgment concemed the delegates at the conventions. CARTER \& STONE, supra note 6, at 45 (Sept. 4, 1821) (statement of Mr. Tallmadge); Clarke, supra note 6, at 14 (Sept. 4, 1821) (statement of Mr. Tallmage); Bishop \& ATTREE, supra note 6, at 371. See also supra note 304.

306. BishOP \& ATTREE, supra note 6, at 371 (statement of Mr. Ruggles, chairman of the committee on the judiciary); 2 Dougherty, supra note 6, at 173.

307. Writers on the 1846 constitution have ignored its reduction in popular influence on the courts through its elimination of senatorial judges. E.g., Leamed Hand, The Elective and Appointive Methods of Selection of Judges, 3 PROC. ACAD. POL. SCI. N.Y. 82, 82 (1913) 
New York's conscious reliance on its senators to reform the law through judicial decisions also calls into doubt the claim that judicial activism is a modern invention. 308 Although the Federalist asserted that the judicial branch had neither "FORCE nor WILL, but merely Judgment," 309 New Yorkers' decision to adopt senatorial judges demonstrated their belief that judicial decisions depend on who judges the case and on that person's will, not merely on abstract deduction from immutable principles. New York's judicial role for senators also suggests that New Yorkers believed that the courts had advantages over legislatures in changing the law. Reacting to cases as they arose before them, the courts could immediately respond to potential injustices and issue a decision with retroactive effect.

These considerations in turn suggest that the framers of New York's constitutions believed the primary function of the judiciary was to provide Justice in a way that the legislature could not, rather than providing an anti-majoritarian check on an untrustworthy legislature. 310 This emphasis on the creative function of the judiciary, as opposed to its checking function, is exemplified by the early New Jersey constitution. This constitution did not allow the courts to review legislative decisions for violations of the state constitution. ${ }^{31}$ ! However, it allowed a higher court composed predominantly of legislators to review judicial decisions. 312

(the decision to elect judges was adopted "under the full tide of Jacksonian democracy"); Caleb Nelson, A Reevaluation of Scholarly Explanations for the Rise of the Elective Judiciaryin Antebellum America, 37 AM. J. LEC. HIST. 190, 192 (1993) (Mississippi had elected judges "well before New York," ignoring the elected senatorial judges). Nelson even ascribes to the appointment process, rather than to the senators' serving as judges, a statement that in "“all causes in which the constitutionality of an act of the legislature was drawn in question... the point in dispute must necessarily have been prejudged in passing the law." Nelson, supra, at 205. On the other hand, the argument that a desire for a professional bench promoted an elected judiciary, see Hall, supra note 57 , acquires force from the rejection of lay, partisan senatorial judges.

308. The role of judges as active modifiers of the law supports treating judges as "representatives" under the Voting Rights Act. See Chisom v. Roemer, 501 U.S. 380, 398-99 (1991). But cf. id. at 400 (claiming that the framers of the federal Constitution and states constitutions believed that "ideally public opinion should be irrelevant to the judge's role") (citing Glenn R. Winters, Selection of Judges-An Historical Introduction, 44 TEx L. REv. $1081,1082-82$ (1966)). Winters neglects the dual legislative and judicial roles of New York's senators. 44 TEX. L. REV. at 1082.

309. The Federalist No. 78, at 465 (Alexander Hamilton) (Clinton Rossiter ed., 1961)

310. Cf. Steven P. Croley, The Majoritarian Difficulty: Elective Judiciaries and Rule of Law, 62 U. ChI. L. Rev, 689 (1995) (arguing that elective judiciaries will be unable to oppose popular sentiments that are in conflict with the constitution).

311. Indecd, the legislature amended the Constitution by ordinary legislation. N.J. Act of September 20, 1777, set out as N.J. Const. of 1776 preamble note, N.J. STAT. ANN. ConST. p. 600 (West 1971).

312. N.J. CONST. of 1776 art. IX. 


\section{B. Lay Judging and Public Choice Theory}

It is a seeming paradox that the supposedly most democratic members of the court were those that, to use Horwitz' words, "actively promoted a legal redistribution of wealth against the weakest groups in the society," 313 over the objections of elite judges. Why did the senatorial judges, elected by "universal," adult, white, male suffrage, promote the interests of business at the expense of consumers, farmers, and laborers, while the educated, professional judiciary opposed business and commercial interests? The obvious explanations of electoral responsibility simply do not fit.

To address this discrepancy, we must turn to public choice theory. Public choice theory attempts to explain why government acts as it does by considering the influence of governmental officials' self-interest on governmental behavior. To stay in office, elected officials must favor those who can organize. Large groups have difficulty organizing, and each member is tempted to wait in the hopes that someone else will undertake the burden. Groups such as "consumers fare badly in the legislative process: They are too numerous to organize an effective 'cartel' in support of or in opposition to existing or proposed legislation." 314 Individuals may not notice small amounts of harm, and even if they do, the harm may be smaller than the inconvenience of seeking retribution from the official responsible. 315 The comparatively few men in commerce, by contrast, can more easily organize to influence elections, and therefore have greater success in obtaining favorable decisions from elected officials.

The comparative immunity of judges from the influences that can be brought to bear on legislators suggests, public choice theorists believe, that judges adopt better rules of law than legislators. 316 The contrast between the incentives for legislative and professional judges explains both the senatorial judges' predilection for rules that may have hurt their constituents by "promot[ing] a legal redistribution of wealth against the weakest groups in the society" 317 and the professional judges' resistance

313. $I d$.

314. POSNER, supra note 9 , at 525.

315. See, e.g., James D. Gwartney \& Richard E. Wagner, Public Choice and the Conduct of Representative Government, in Public Choice and Constitutional Economics 3, 19 (James D. Gwartney \& Richard E. Wagner ed, 8); POSNER supra note 9, at 526.

316. E.g., William N. Eskridge, Jr., Politics Without Romance: Implications of Public Choice Theory for Statutory Interpretation, 74 VA. L. Rev. 275, 307 (1988). But see Paul Rubin, Common Law and Statute Law, 11 J. Legal Stud. 205 (1982). Agreement on the superiority of judges conceals disagreement over what they promote. Compare Posner supra note 9, at 523 (judges promote economic efficiency) with Richard A. Epstein, The Static Conception of the Common Law, 9 J. LeGAL. STUd 253, 272 (1980) (judges promote respect for pre-existing rights); RICHARD A. EPSTEIN, TAKINGS vii (1985) (same).

317. HoRwITZ, supra note 3, at 254. 
to the same innovations. These conclusions support Horwitz' argument that the changed rules were inefficient subsidies. 318

Additional evidence for the superiority of the substantive rules of law favored by judges is the contemporary reversal of many of the rules that the lay judges adopted. The holder-in-due-course doctrine no longer applies to consumer contracts. 319 The fair price doctrine has been followed as a matter of common law, 320 in the Uniform Commercial Code's provisions making contracts for an excessive price unenforceable for unconscionability, 321 and in more specific statutes. 322 The Uniform Commercial Code has abolished virtual acceptance 323 and much of the difference between a sale and a transfer for security of negotiable instruments. 324 The fifth amendment's prohibition of takings has been applied to state takings of private property, ${ }^{325}$ despite its initial limitation to federal takings, 326 overturning the nineteenth-century state rules that allowed unlimited taking of private property for the public good.327

That the entity reversing the decisions of the lay judges generally avoided the interest-group politics associated with legislation also suggests that the lay judge decisions responded to political influence, not social needs. State takings law was reversed by the United States Supreme Court as a matter of federal constitutional law. Holder-in-due-course law

318. Id. at 99-101.

319. 16 C.F.R. $\$ 433.2$ (1994); Statement of Basis and Purpose for Trade Regulation Rule Concerning Preservation of Consumers' Claims and Defenses, 40 Fed. Reg. 53,524 (1975). See also James White \& Robert S. Summers, Uniform Commercial Code $\$ 14-8$, at 638 (3d ed. 1988). See generally Michacl M. Greenfield \& Nina L. Ross, Limits on a Consumer's Ability to Assert Claims and Defenses under the FTC's Holder in Due Course Rule, 46 Bus LAW. 1135 (1991).

320. People ex ref. Hartigan v. Knecht Servs., 216 Ill. App. 3d 843, 854, 575 N.E.2d 1378, 1385 (1991); Ahem v. Knecht, 202 Ill. App. 3d 709, 716, 563 N.E.2d 787, 792 (1990). But see Patterson v. Walker-Thomas Furniture Co., 277 A.2d 111 (D.C. 1971). Cases involving price alone are scarce; almost all of the cases involving substantively unconscionable contracts also involve procedural impediments to the understanding of the party to be held liable on the contract. WHITE \& SUMMERS, supra note 319, $\$ 4-7$.

321. WHITE \& SUMmerS, supra note $319, \S 4-5$ (3d ed. 1988) (citing Toker v. Westerman, 113 N.J. Super. 452, 454, 274 A.2d 78, 80 (N.J.L. 1970); American Home Improv. Inc. v. Maclver, 105 N.H. 435, 201 A.2d 886 (1964)).

322. People ex rel. Abrams v. Two Wheel Corp., 71 N.Y.2d 693525 N.E.2d 692, 530 N.Y.S.2d 693 (1988) (gross disparity in prices in electric generators during a power outage caused by a hurricane violated New York's anti-price-gouging statute) (relying on N.Y. Gen. Bus. Law 396-r (Consol. 1980)).

323. U.C.C. \& 3-410(1) official comment, purposes of change, para. 3 (1994).

324. U.C.C. \$9-102 \& official comment (1994). However, U.C.C. § 3-303(a)(2) (1994) abolishes the differences by treating even those who acquire a security interest in an instrument as satisfying the requirement that a transfer be for value.

325. E.g., Dolan v. City of Tigard, 114 S. Ct. 2309 (1994); Pennsylvania Coal Co. v. Mahon, 260 U.S. 393, 413 (1922).

326. E.g., Barron v. City of Baltimore, 32 U.S. (7 Pet.) 243, 247-48 (1833).

327. See Note, William Treanor, The Origins and Original Significance of the Just Compensation Clause of the Fifth Amendment, 94 YALE L.J. 694, 695-701 (1985). 
was reversed by the Federal Trade Commission, a group comparatively immune from popular pressure. 328 Indeed two prominent commentators have contrasted the independent action of the FTC with the reticence of legislators: "In one stroke of their pen the clever rascals at the FTC did what Congress would have feared to do, what the courts could do only piecemeal, and what state legislatures had refused to do."329 The Uniform Commercial Code was drafted outside the usual legislative process and presented to each state with injunctions against creating a lack of uniformity. 330

There are some counter-arguments to the conclusion of public choice theory that the modification of the decisions of lay judges by disinterested groups suggests the correctness of those modifications. First, courts have so rarely ruled that excessiveness of price invalidates a sale, one cannot with confidence infer that the fair price doctrine is sound or even that the law has changed from the lay judges' time.

Second, changed circumstances may have allowed or required rejecting precedents that were sound when the lay judges promulgated them. Such an argument seems especially plausible for negotiable instruments law, because the need for money in the 1820 s and 1830 s, which may have promoted broad negotiability and the holder-in-due-course doctrine, no longer exists.

However, this attempt to defend the work of lay judges through changed circumstances seems to fail, because negotiable instruments law provides the most apparent subsidization of commerce through harm to consumers. A mere transfer of money from some group to another will seldom promote efficiency. 331 Enforcing negotiability meant depriving the signer of promissory notes of defenses that would have been available in actions by the payee of the note. The signers of the notes could have expressly waived their defenses, but did not, and many signers did not realize that they would lose their defenses of fraud and deception in actions brought by holders in due course. 332 As Horwitz observes, judges from states other than New York argued that depriving promisors of these defenses would "countenance...frauds" 333 and "bind a man contrary to express agreement, and the real equity of the case." 334

Public choice theory's critique of legislative decisions, as corrobo-

328. Eskridge, supra note 316 , at 308.

329. WhITE \& SUMMERS, supra note $319, \S 4-7$, at 639.

330. U.C.C. $\$ 1-102(2)$ (c) (1994).

331. Ronald Coase, The Problem of Social Cost, 3 J. L. \& Econ. 1 (1960).

332. HorwITZ, supra note 3, at 219 n.30 (citing 3 WILLIAM GrIfFITH, ANNUAL LAW ReGister [7] (1822) (according to Horwitz, the version in the Harvard Law Library contains this, but the Amo Press reprint does not)).

333. Norton v. Rose, 2 Wash. 233, 252 (Va. 1796), cited in HoRwITZ, supra note 3, at 219 n.29. See also id. at 253 (Lyons, 1.) ("protect fraud").

334. Rhodes v. Risley, 1 Chip. Rep. *84, *87 (Vt. 1791) (2d ed. 1888), cited in HorwiTz, supra note 3 , at 218 n. 28 . 
rated by the results of lay judging, may tempt one to broaden the scope of decisions made by judges. 335 However, history and public choice theory also suggest that the professional judges were themselves sometimes systematically wrong.

First, public choice theory implies that the procedural decisions of the lay judges probably did maximize welfare, because such decisions generally do not have identifiable beneficiaries. 336 Thus, allowing setoffs favors defendants, but the defendants may not belong to any predictable class of society.

Second, the procedural changes promoted by lay judges have generally been accepted, suggesting these changes may have been correct. For example, current procedural rules, often adopted by groups immune from political pressure, allow or even require broad counterclaims and setoffs. 337 Statutory procedural innovations may also have been adopted more quickly because of the familiarity that lay judges had with the judicial process. Certainly, the Field Codification concept advanced most rapidly in New York.

The lay judges were also free from conflicts of interest created by the professional judges' roles. For example, a statute awarding double costs to prevailing defendants who were sheriffs or other officers likely to be sued was interpreted by the professional judges to make the costs payable to the attorney. 338 This decision seems difficult to justify on the merits, because the attorney incurred no special risks as a result of defending the case, but the sheriff did incur special risks as a result of his position. Therefore, the professional judges' status as attorneys may explain their decision. 339

The issue of the appealability of denials of writs of habeas corpus may also have presented a conflict of interest. In arguing that such denials were not appealable, the professional judges attempted to preserve unreviewable discretion for themselves, a discretion which the lay judges found that the professional judges had erroneously exercised by confining someone to jail. 340 The lay judges' intervention to support a fundamental

335. Eskridge, supra note 316, at 307; EPSTEIN, supra note 316.

336. Eskridge, supra note 316, at 323.

337. See, e.g., Fed. R. Civ. P. 13. These rules have the imprimatur of the Supreme Court and are written by an advisory committee, see Statement of Justice White, 146 F.R.D. 501, $502 \&$ n.2 (1993), so that the rules, like the Uniform Commercial Code, largely escape the interest-group pressures of the legislative process.

338. See supra note 194.

339. See Richard A. Epstein, The Independence of Judges: The Uses and Limitations of Public Choice Theory, 1990 B.Y.U.L. Rev. 827, 833 (judges may seek to "satisfy themselves or their close friends"); Jonathan R. Macey, Judicial Preferences, Public Choice and the Rules of Procedure, 23 J. Legal Stud. 627, 631 (1994) (judges' 'investment in the legal system is likely to align their preferences with the preferences (and interests) of the legal community as a whole").

340. See supra note 15. 
right seems justified by the professional judges' special interest. 341

The lay judges' successes suggest a difficulty with public choice theory's prescription for empowering the judiciary. Particularly in the case of appeals from denials of habeas corpus, the lay judges thwarted decisions by professional judges that would have reserved decisions to professional judges. Madison observed that "pre-eminence and power" are goals in themselves and that power can be used to advance non-financial opinions about religion and government as well as financial interests. ${ }^{342}$ Although judges have no pecuniary interests in the outcome of lawsuits, their nonpecuniary interests are unchecked. Indeed, their insulation from popular pressure means that they may more freely indulge their nonpecuniary interests than legislators. 343

For this reason, it is interesting that three of the earliest and most influential proponents of the argument that public choice theory344 implies that courts produce better rules than legislators are Judge Frank Easterbrook, 345 Judge Richard Posner, 346 and Justice Antonin Scalia. 347 These proponents of social choice theory conclude from this that judicial decisions are more to be trusted than legislative decisions and therefore favor a variety of devices to expand judicial power. These include interpreting statutes restrictively, which leaves the decision up to the pre-existing judge-made law348; interpreting statutes in a common-law fashion, which allows judges their traditional rule-making powers ${ }^{349}$; and ignoring legislative intent, which leaves, as Justice Scalia admits, "judicial wilful-

341. The decision and Chief Justice Kent's arguments in it for non-reviewability "served only to lay him open to the charge of exalting judicial authority at the expense of personal freedom." HORTON, supra note 19, at 186-87.

342. The Federalist No. 10, at 79 (James Madison) (Clinton Rossiter ea., 1961). See also GEORGE ORWell 1984, at 217 (Penguin 1981) (1949) (the "object of power is power"). Fofessor Alexander has catalogued possible biases of judges that may affect their decisions. Janet Cooper Alexander, Judges' Self-Interest and Procedural Rules: Comment on Macey, 28 J. LEGAL STUD. 647, 660-65 (1994).

343. See Epstein, supra note 339 , at 845.

344. See, e.g., Eskridge, supra note 316, at 314 (Posner and Easterbrook "initial" and "influential"); id. at 277 (citing Scalia's 1985 opinions as using public choice arguments and Posner's and Easterbrook's early articles).

345. Frank Easterbrook, Statutes' Domains, 50 U. CHI. L. Rev. 533 (1983); Frank Easterbrook, The Supreme Court, 1983 Term-Foreword: The Court and the Economic System, 98 Harv. L. Rev. 4 (1983).

346. Richard Posner, The Federal Courts 286-93 (1985); Richard Posner, Economics, Politics, and the Reading of Statutes and the Constitution, 49 U. CHI. L. REv. 263 (1983); Richard Posner, Statutory Interpretation-in the Classroom and in the Courtroom, $50 \mathrm{U}$. ChI. L. Rev. 800 (1983);

347. E.g., Hirschey v. FERC, 777 F.2d 1, 7-8 \& n.1 (D.C. Cir. 1985) (Scalia, J., concurring).

348. Frank Easterbrook, Statutes' Domains, 50 U. CHI. L. Rev. 533, 544-45 (1983).

349. Richard Posner, Legal Formalism, Legal Realism and the Interpretation of Statutes and the Constitution, 37 CASE W. REs. L. REv. 179 (1986-87). 
ness" unconstrained. 350 These judicial activists are behaving exactly as public choice theory predicts they would act to advance their non-pecuniary agendas.

The history of New York's lay judges and their professional colleagues suggest that the susceptibility of elected officials to interest-group politics and the special interest of the judiciary both skew decisions. Public choice theorists should consider both in making normative judgements about courts and legislatures and the tasks appropriate to each.

\section{CONCLUSION}

The senatorial judges were expected to influence judicial decisions away from technicalities and in favor of popular interests. Although the senatorial judges contributed to procedural reform, they were instrumental in the adoption of the pro-business and anti-popular changes to the common law about which Professor Horwitz writes. In suggesting limitations on Professor Horwitz' thesis, I am not arguing for the revival of a Whig history of commercial law, but for a recognition of the fundamental role of procedural devices in the development of substantive law. Conversely, in suggesting limits on the desirability of judicial independence and public choice theory's endorsement of judicial rule-making, I am not arguing for the greater politicization of the judiciary, but for public and legislative recognition of the special interests and biases of judges. With respect to both issues, the larger significance of this work may be its demonstration of the relevance of historical data to provide empirical tests for claims about contemporary issues.

350. Daniel A. Farber \& Philip P. Frickey, Legislative Intent and Public Choice, $80 \mathrm{VA}$. L. Rev. 423, 455 (1988) (quoting Address by Justice Antonin Scalia, Speech on Use of Legislative History) (delivered between fall 1985 and spring 1986 at various law schools in varying forms) (copy on file with Virginia Law Review Association). 